\title{
Case Studies of Community Resilience and Disaster Recovery from the 2013 Boulder County Floods
}

\author{
Christopher T. Clavin \\ Zoe E. Petropoulos \\ Nayanee Gupta \\ Christopher K. Tokita \\ IDA Science and Technology Policy Institute
}

This publication is available free of charge from:

http://doi.org/10.6028/NIST.GCR.16-011

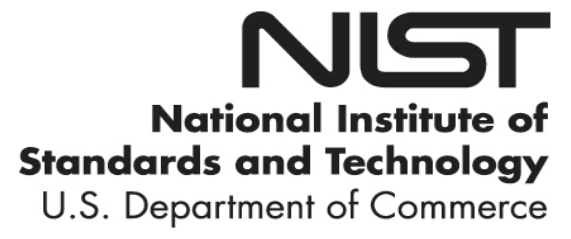





\section{Case Studies of Community Resilience and Disaster Recovery from the 2013 Boulder County Floods}

Prepared for U.S. Department of Commerce

Operating Unit National Institute of Standards and Technology

Gaithersburg, MD 20899

Christopher T. Clavin Zoe E. Petropoulos Nayanee Gupta Christopher K. Tokita IDA Science and Technology Policy Institute

This publication is available free of charge from:

http://doi.org/10.6028/NIST.GCR.16-011

April 2017

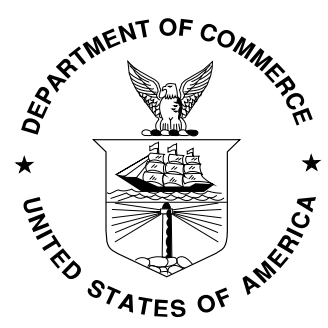

U.S. Department of Commerce Wilbur L. Ross, Jr., Secretary 


\section{Acknowledgments}

This work was partially funded by the Office of Standards within the Capability Development Support group, Department of Homeland Security Science and Technology Directorate. The work described was funded by the United States Government and is not subject to copyright.

The authors greatly appreciate the time and energy that officials and residents from Boulder County, the City of Boulder, the Town of Lyons, the Town of Jamestown, and the City of Longmont shared with us. Their insights and experiences were fundamental to preparing this report and ensuring their lessons could be documented to advance community resilience efforts and to share with other communities. 


\section{Executive Summary}

In September 2013, an area of the Rocky Mountains region referred to as the Colorado Front Range experienced unprecedented rainfall that resulted in multiple days of flooding. This flooding caused significant damage to homes, commercial structures, roads, bridges, infrastructure systems, and parks and open space across the region, including Boulder County's communities and mountain towns.

Flooding, particularly flash flooding, is a primary hazard of concern in the region. The City of Boulder and Boulder County have implemented programs and preparedness measures to mitigate the risk, respond to, and recover from floods. Boulder County communities have been investing for decades to improve infrastructure systems, avoid development in hazard-prone areas, and implement financial and administrative programs to mitigate potential flooding damage. Government officials who had gained experience during the 2010 Fourmile Canyon Wildfire were also responsible for ensuring that their communities had the resources and support necessary to rebuild and restore community services after the 2013 flood. In the years since the 2013 flood, communities have rebuilt and recovered with an emphasis on reducing future vulnerability. The collective experiences of those who helped prepare for and recover from the Boulder County flood are documented in this series of case studies of community resilience planning.

The IDA Science and Technology Policy Institute, with support from the National Institute for Standards and Technology (NIST) Community Resilience Group, conducted case studies of Boulder County community resilience planning before, during, and after the 2013 flood. Three case studies focus on unincorporated Boulder County, the City of Boulder, and the towns of Lyons and Jamestown. A primary focus of the research was to document the recovery efforts within each case study; the programs, policies, or broader efforts employed by each community to design and construct resilient infrastructure; and the efforts to ensure community services (e.g., housing and public health) were provided throughout the multi-year recovery process. Research is based on publicly available literature, including reports published by Boulder County governments, and discussions with Boulder County community officials in 2015 and 2016.

\section{Boulder County Flood Resilience Planning: Practices and Lessons Observed}

The following list of practices and observations of resilience efforts demonstrated by government officials within Boulder County describe activities highlighted in discussions 
with Boulder County community government officials or described in literature as important facets of comprehensive flood preparedness and recovery efforts. Boulder County communities' experiences since 2013 are likely useful to inform the design of community resilience planning guidance and serve as useful examples to inform other communities' resilience program planning and implementation.

\section{Infrastructure Design, Planning, and Implementation}

1. Stormwater and flood management planning provided long-term guidance for investments in flood management infrastructure.

2. Stormwater and flood management programs incorporated a broad array of initiatives to increase flexibility of program managers to meet community objectives. Initiatives such as property acquisition, regular floodplain map updates, and land-use restrictions provided program managers tailored solutions to meet mitigation and community goals.

3. Engineered waterways served multiple community objectives, such as flood management, ecological preservation, recreation, and cultural resource preservation. Commercial and residential development was restricted on floodplains. Flood hazard zones were developed for other uses, such as public recreation facilities.

4. Up-to-date floodplain maps are essential to mitigate damage from floods. The 2013 floods altered some of the existing waterways and floodplains, which required communities to update floodplain maps. These maps provide the basis for establishing critical facility flood mitigation requirements. (See Infrastructure Design, Planning, and Implementation summary item 7.) Floodplain map updates were used with risk assessment processes to increase the utility of floodplain maps to community decision makers.

5. Boulder County communities developed a resilient design performance standard for infrastructure and dependent facilities. The Boulder County Collaborative, a group of city, town, and county governments from the flood-affected communities, developed a resilient design performance standard that established a three-step process for evaluating proposed infrastructure projects against community-specific resilience objectives. Boulder County officials used NIST's Community Resilience Planning Guide for Buildings and Infrastructure Systems to design this standard and are implementing it to comply with requirements of the U.S. Department of Housing and Urban Development's Community Development Block Grant Disaster Recovery program.

6. Infrastructure interdependencies were a significant source of vulnerability. Some of the most significant effects of the 2013 flood were the failure of 
infrastructure systems that depended on other infrastructure to function properly. Most notably, power outages and road damage affected water infrastructure systems. Potential events that were judged near misses were also related to infrastructure interdependencies.

7. Regulatory measures were implemented to ensure critical public safety and lodging facilities would be operational after a flood. These regulatory measures required critical facilities in areas where flooding has an annual 1 percent or 0.2 percent chance of occurring (these areas are called the 100-year or 500-year floodplains, respectively) to adequately protect against floods or relocate outside the floodplain to ensure continuity of public safety services and protection of vulnerable populations in a flood.

\section{Administration Actions to Serve Community Needs}

1. Disaster Assistance Centers (DACs) streamlined the provision of community services. Coordinated and staffed by Boulder County and City of Boulder officials, DACs provided critical information and resources for residents as they navigated the rebuilding and recovery process in the months after the event. These centers also provided a central location for government officials to acquire information on flood impacts, resident needs, and recovery plans.

2. Government interdepartmental coordination functions were established to facilitate recovery-phase efforts. These efforts required municipal governments to ensure that departments provided a unified set of public services to residents, aided application and approval processes, and ensured that communities would be eligible for public assistance funding. Interdepartmental coordination was necessary to integrate long-term recovery with traditional departmental roles and responsibilities.

3. Additional structure and protocols were needed to transition municipal government roles and responsibilities from the response phase to the recovery phase. The City of Boulder identified that improvements were needed to increase the efficiency of shifting staff emergency response roles to long-term recovery roles. Officials noted the need to plan recovery-phase roles before an event occurs to smooth out response and recovery-phase transitions.

4. Early and sustained engagement with community members who provided input to recovery planning helped government officials with implementing effective resilience plans. Officials relied upon this participatory planning process with the community to ensure that they received input on recovery goals, programs, and projects. 
5. Elected officials provided emergency waivers and granted government agencies special authorities to meet public service needs during recovery. Elected bodies of multiple community governments passed emergency ordinances to grant waivers for permit fees and to establish temporary moratoriums on building permits to ensure that building codes were enforced.

6. Budgetary reserves for emergencies provided communities the flexibility to prioritize local needs and requirements. These reserves provided funding for administrative requirements that were later reimbursed through Federal disaster assistance. The availability of financial reserves that could be quickly accessed by community management enabled quick implementation of infrastructure restoration projects. These funds also enabled communities to set priorities for recovery without immediately affecting other government programs and budgets.

7. The Boulder County Collaborative provided governmental decision-making capacity across several jurisdictions in the region where flooding took place. This unique decision-making body was created through intergovernmental agreements to ensure fair prioritization, distribution, and allocation of disaster recovery funds provided by the Community Development Block Grant Disaster Recovery (CDBG-DR) program. This situation is notable because decisionmaking roles are generally assumed by State-level agencies rather than regional governmental bodies. Boulder community officials found this coordination structure to be particularly useful compared to the standard CDBG-DR funding allocation process, where communities submitting potentially competing recovery proposals to the state government.

8. Boulder community officials recognized the role of an organization that bridged multiple community to capture and address long-term recovery needs. BoCo Strong was formed to increase the strength of the community's social networks and resilience infrastructure. This group is attempting to address crosscommunity resilience needs that often sit outside traditional municipal government roles. 


\section{Contents}

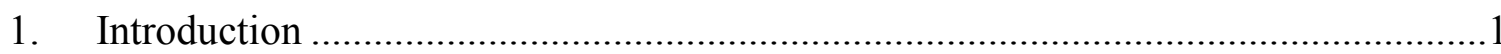

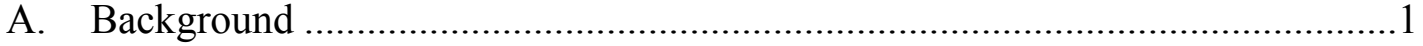

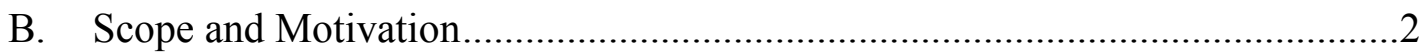

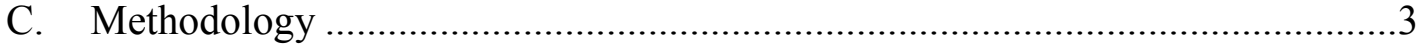

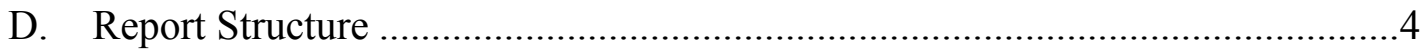

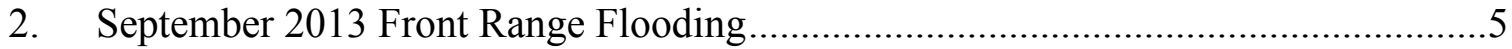

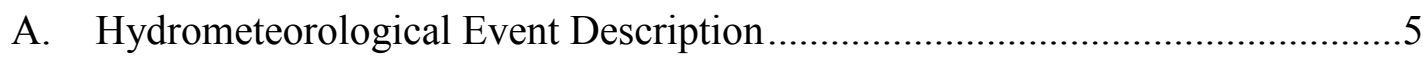

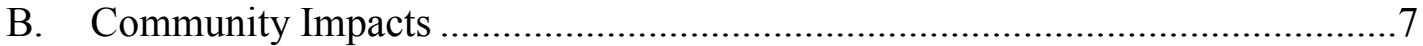

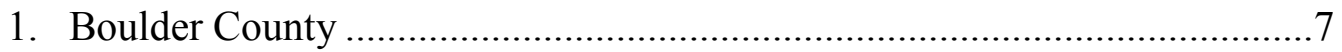

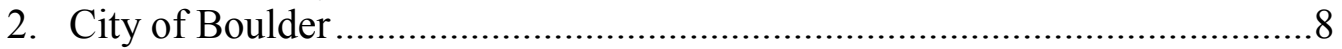

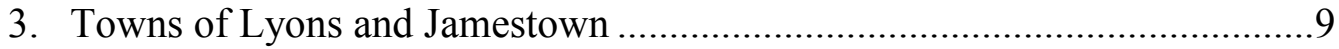

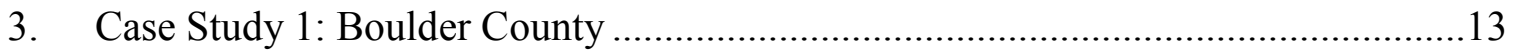

A. Pre-Flood Preparedness ..............................................................................13

1. Recovery Structure Established Following the Fourmile Canyon Fire........13

2. Emergency Management Coordination and Governance Structure .............13

B. Emergency Response and Short-Term Recovery Actions and Decisions..........14

1. Context and Over-Arching Considerations during the Immediate Response........................................................................................14

2. Governance Structure for Emergency Response Actions and Decisions....14

3. Establishment of County Recovery Leadership Group ................................15

4. Infrastructure Recovery Actions and Decisions ..........................................16

5. Actions and Decisions Related to Community Needs...................................18

6. Summary of Emergency Response Actions and Decisions...........................19

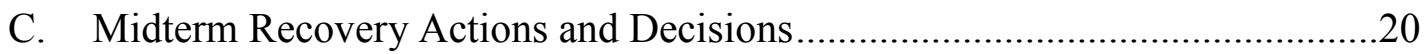

1. Context and Considerations for Midterm Recovery Efforts ........................20

2. Infrastructure Recovery Actions and Decisions .........................................20

3. Actions and Decisions Related to Community Needs...................................23

4. Summary of Midterm Actions and Decisions ............................................24

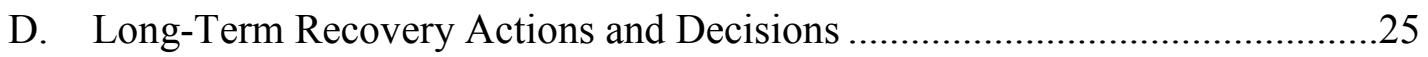

1. Context and Considerations for Long-Term Recovery Efforts ....................25

2. Governance Structure for Long-Term Recovery Actions and Decisions....26

3. Infrastructure Restoration Actions and Decisions ......................................26

4. Actions and Decisions Related to Community Needs.................................28

5. Boulder County Collaborative for CDBG-DR Funds Allocation ................29

6. Summary of Long-Term Actions and Policy Decisions ...............................30

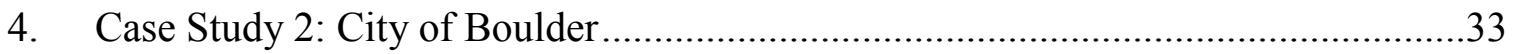

A. Pre-Flood Preparedness Planning and Programs..............................................33

1. Comprehensive Stormwater Management Planning ....................................33 


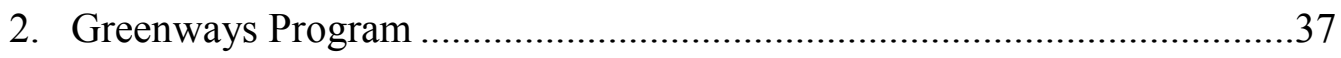

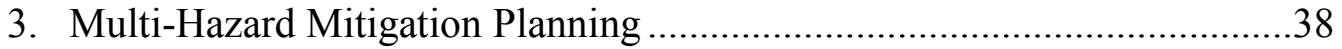

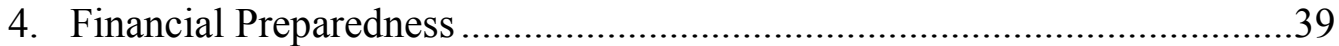

5. Summary of Pre-Flood Preparedness Planning and Programs......................39

B. Emergency Response Actions and Decisions ..................................................40

1. Governance Structure for Emergency Response Actions and Decisions ....40

2. Infrastructure Impacts and Emergency Maintenance Actions .....................41

3. Open Space and Natural Resource Impacts ...............................................43

4. Resident Needs and Impacts.....................................................................44

5. Summary of Emergency Response Actions and Decisions...........................45

C. Midterm Recovery Actions and Decisions.......................................................46

1. Context and Considerations for Midterm Recovery Efforts .........................46

2. Recovery Governance Structure and Establishment and Organization of the City Flood Recovery Structure......................................47

3. Midterm Resident Needs and Public Services ............................................49

4. Ordinance for Mandatory Flood Protection for Critical Facilities and

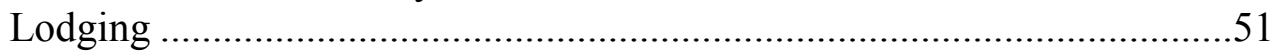

5. Financial Resources Available to the City Government ..............................52

6. Summary of Midterm Recovery Actions and Decisions ...............................52

D. Long-Term Recovery Actions and Decisions …………................................54

1. Context and Considerations for Long-Term Recovery Efforts .....................54

2. Long-Term Infrastructure Recovery ......................................................54

3. Administration of Long-Term Recovery..................................................56

4. Open Space and Natural Resources.............................................................61

5. Summary of Long-Term Recovery Actions and Decisions .........................62

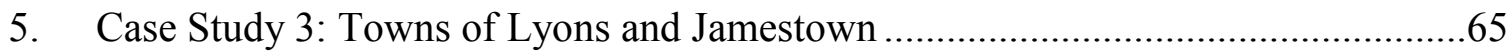

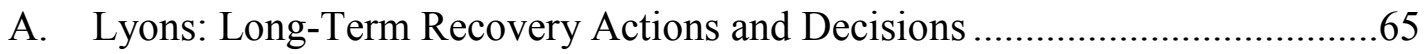

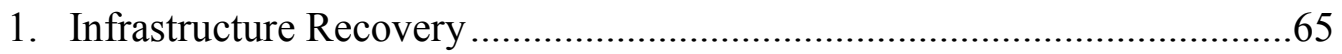

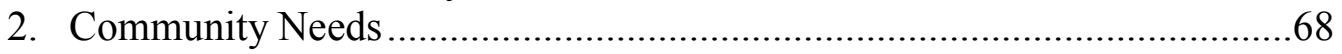

B. Jamestown: Long-Term Recovery Actions and Decisions ................................69

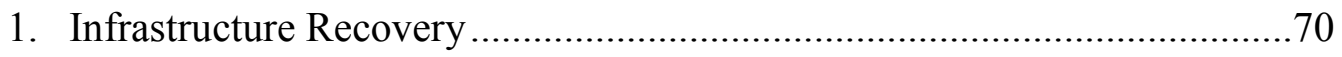

2. Community Needs ………………………………................................

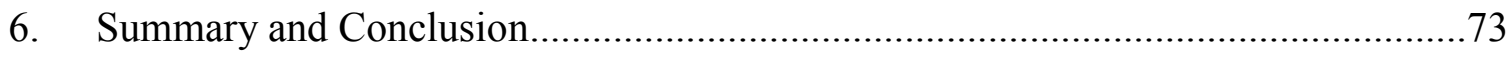

A. Infrastructure Design, Planning, and Programmatic Implementation ................73

1. Strategic Stormwater and Flood Management Planning Provided LongTerm Guidance for Investments in Flood Management Infrastructure........73

2. Designing Stormwater Programs That Incorporated a Broad Array of Initiatives Increased Flexibility of Program Managers to Meet Community Objectives

3. Engineered Waterways Can Serve Many Community Objectives, Including Flood Management, Ecological Preservation, Recreation, and Cultural Resource Preservation

4. Up-to-Date Floodplain Maps Remain the Primary Input for Effective Designs to Mitigate Damage from Floods ... 
5. Boulder County communities Implemented Resilient Design Performance Standards for Infrastructure and Dependent Facilities............74

6. Infrastructure Interdependencies Were a Significant Source of Vulnerability.....

7. Regulatory Measures Were Implemented to Ensure That Critical Public Safety and Lodging Facilities Would Be Operational after a Flood. . .75

B. Administration of Recovery Efforts to Serve Community Needs.

1. DACs and the Flood Recovery Center Streamlined the Provision of Community Services

2. A Government Interdepartmental Coordination Function Was Established to Facilitate Recovery-Phase Efforts

3. Additional Structure and Protocols Were Needed to Transition Municipal Government Roles and Responsibilities from the Response Phase to the Recovery Phase.

4. Early and Sustained Engagement with Community Members Who Provided Input to Recovery Planning Helped Government Officials Implement Effective Restoration Plans.

5. Elected Officials Provided Emergency Waivers and Granted Government Agencies Special Authorities to meet Public Service Needs during Recovery

6. Budgetary Reserves for Emergencies Provided Communities the Flexibility to Prioritize Local Needs and Requirements and Provided Funding for Administrative Requirements for Later Reimbursement through Federal Disaster Assistance

7. The Boulder County Collaborative Provided Governmental DecisionMaking Capacity across Several Jurisdictions in the Region Where Flooding Took Place

8. Boulder Community Officials and Local Non-Profit Organizations Recognized the Role of Resident-Led Organizations in Addressing Long-Term Recovery Needs

Appendix A. Discussion Topics

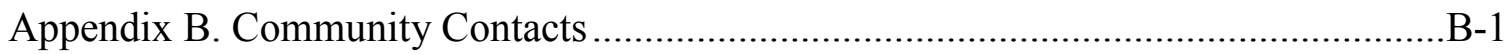

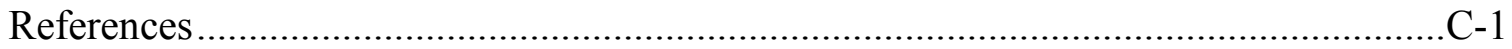

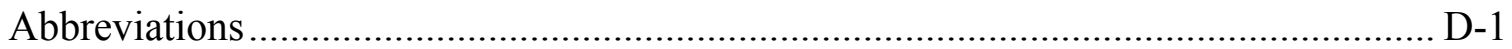




\section{Introduction}

\section{A. Background}

On September 9, 2013, a cold front stalled over Colorado, colliding with warm humid air from the south, bringing about near-continuous rainfall to the region until September 15. This rain event was considered a 1,000-year event (i.e., 0.1 percent chance of event in a given year), which resulted in massive flooding throughout central and northern Colorado. Across the state, over 19,000 homes and commercial buildings were damaged, with 1,500 destroyed. The flood damaged over 485 miles of roads and caused eight fatalities as a direct result of flooding (National Weather Service 2014). Of the 14 affected counties in the region, Boulder County was one of the hardest hit. Small creeks that are usually dry surged to flood levels and the resulting erosion created new stream paths in some extreme cases. St. Vrain Creek was estimated to reach peak streamflow (674 cubic meters per second) that was more than double the record peak recorded in 1941 (297 cubic meters per second), and Boulder Creek was estimated to reach a daily-mean streamflow (252 cubic meters per second) that was at least more than twice the magnitude of a record streamflow in 1938 (125 cubic meters per second) ${ }^{1}$ (Kimbrough and Holmes 2015). As result of the complex flooding factors, significant amounts of damage to structures was experienced outside of the designated 100-year floodplain. Within the City of Boulder alone, the total damage to city infrastructure systems and public lands was estimated at \$28 million, with an additional $\$ 200$ million in damages to private property (City of Boulder 2015a).

Boulder County and the communities within it had emergency response and recovery mechanisms already in place, in part as a result of lessons learned from recent disaster events, such as the Fourmile Canyon Fire. Two main objectives of the recovery process after the 2013 flood event were to restore infrastructure systems and meet community needs. The activities to meet these objectives were planned and executed with the understanding that the region is at a high risk of experiencing similar events in the future. Therefore, restoring the infrastructure and community networks to pre-event conditions would be inadequate. The county would need to become more resilient.

\footnotetext{
1 St. Vrain peak streamflow estimate is based on a two-dimensional model estimate of flow rate due to streamgages being destroyed during the flooding event prior to peak flood stage. The Boulder Creek estimate is taken based upon measurements obtained at a streamgage 5 miles upstream of the mouth near the Longmont streamgage.
} 
Community resilience is a complex, multi-dimensional concept that combines social science, engineering, earth sciences, economics, and other disciplines to inform and improve the way communities prepare for, prevent, respond to, and recover from disruptive events, whether those events are due to natural or man-made hazards. A resilient community is able to withstand a hazard event or long-term environmental change with minimum impact and damage, rapidly recover from such events, and reorganize into a fully functioning — or ideally, an improved — system. The approaches demonstrated by Boulder County communities to translate resilience planning processes and documents into programs, rules, ordinances, or other measures can inform future resilience planning by communities and community resilience guidance.

\section{B. Scope and Motivation}

The Community Resilience Program at the National Institute of Standards and Technology (NIST) seeks to inform resilience planning and implementation decisions at the local level through the development and application of science-based metrics for measuring resilience and evaluating resilience-oriented investments. A planning guide, entitled Community Resilience Planning Guide for Buildings and Infrastructure Systems, has been written as part of the Community Resilience Program. It is a resource for communities to develop performance goals for their built infrastructure, based upon the social functions that each building and system serves. The purpose of the voluntary guide is to provide a replicable and scalable community planning process that can be employed by municipal or regional governments to determine long-term resilience goals, develop plans, and identify approaches and actions to improve the performance of the built environment and community resilience. Building upon traditional hazard mitigation, response, and recovery efforts and traditional risk assessment methodologies, the guide considers organizational influences, service and performance expectations, and social dependencies on the built environment. The guide lays out a six-step process for structuring the organizational, social, planning, and technical aspects of community resilience planning and implementation.

NIST tasked the Institute of Defense Analyses (IDA) Science and Technology Policy Institute (STPI) to conduct a case study of the 2013 Colorado flood event and its impact on Boulder County. This case study focuses on the following areas and populations within Boulder County: (1) unincorporated Boulder County, (2) the City of Boulder, and (3) the towns of Lyons and Jamestown. The map in Figure 1 provides an overview of the locations of each of the towns and the City of Boulder within Boulder County and the boundaries of the Boulder Creek-St. Vrain Creek watershed. The response and recovery efforts of city, county, and town governments in Boulder County to the 2013 floods provided a unique opportunity to examine their different efforts across short- and long-term timescales to increase community resilience to flooding and hazard risk. The efforts employed by 
Boulder County, the City of Boulder, the towns of Lyons and Jamestown focused on serving community needs throughout the recovery process, while identifying opportunities to rebuild infrastructure, buildings, and public facilities to design standards that would be more likely to survive or mitigate damage in future flooding events.

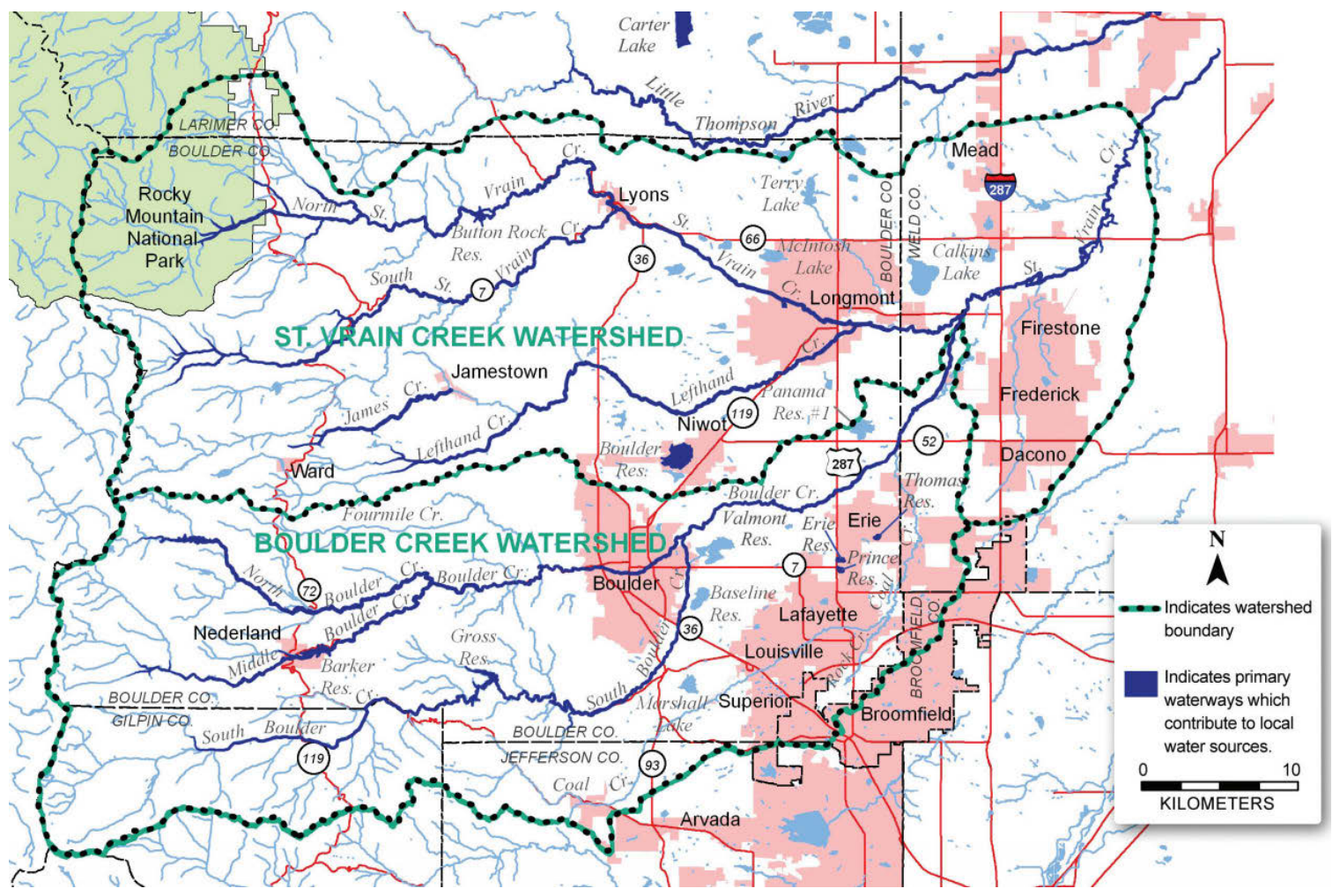

Source: Boulder County Keep It Clean Partnership (2017).

Figure 1. Boulder County Watershed Map

The objective of this work is to understand how post-event hazard preparedness planning and resilience planning has been influenced by the experience of the 2013 floods, particularly with respect to plans, processes, or policies related to community functions, services, and built and natural infrastructure. This report is based on examinations of publicly available literature and discussions with community officials. Case studies in the report describe the Boulder County community efforts and lessons learned in designing and implementing resilience measures.

\section{Methodology}

The data collected for the case studies were found in publicly available literature, including documents published by municipal government agencies, or collected through in-person and telephone discussions, which were conducted in a kickoff meeting (November 2015), in-person discussions with Boulder County government officials 
(March 2016), and in-person discussions with City of Boulder officials (April 2016). A structured protocol (see Appendix A) was used for the discussions to ensure consistency in data collection across the three case studies. Where a citation is not provided, the observation noted in this report was collected in discussions with community officials.

\section{Report Structure}

Chapter 2 provides an overview of the hydrometeorological event that led to the 2013 Colorado floods and a description of the impacts of the flood in each of the respective case study locations.

Chapters 3 through 5 are individual case studies for each of the following: unincorporated Boulder County, the City of Boulder, and the towns of Lyons and Jamestown. The first two case studies, Boulder County and City of Boulder, are organized into pre-event preparedness, emergency response, midterm recovery, and long-term recovery. Many of the activities that these communities implemented before, during, and after the flood spanned more than one of these time periods. In an effort to maintain a cohesive narrative, STPI researchers attempted to capture activities in the time period in which they began and note instances in which communities took further action at a later time. The case study examining efforts in the towns of Lyons and Jamestown follows an organizational structure that highlights the impacts of the flood on infrastructure and community services and describes community efforts since the flood to restore these systems and services. Each case study describes observations related to governance structures employed, a review of infrastructure repair and recovery decisions, and policy decisions related to recovery of community services for each time period.

Chapter 6 captures findings from the three case studies.

The two appendices included in this report include a list of discussion questions and a list community officials who participated in discussions in late 2015 and early 2016. 


\section{September 2013 Front Range Flooding}

\section{A. Hydrometeorological Event Description}

Boulder County experienced a historic flooding event in September 2013 following unusual weather conditions, which lead to a record $432 \mathrm{~mm}$. (17 in.) of rainfall over a week. On September 9, 2013, a cold front stalled over Colorado, and collided with warm humid air from the south. These conditions caused rain to fall almost continuously from September 9 to September 15. By the morning of September 11, the National Weather Service released a statement that the soils of the Front Range were already saturated and warned that any further rainfall would have difficulty being absorbed by the ground (McGhee 2013). Between 6:00 p.m. on September 12 and 6:00 p.m. September 13, 231 $\mathrm{mm}$. (9.08 in.) of rain fell, bringing the 5-day total to $374 \mathrm{~mm}$. (14.71 in.) and nearly exceeding the county's annual average during this one storm (Henson 2013). After the event, the National Weather Service deemed the deluge a 1,000-year rain event (i.e., 0.1 percent chance of event in a given year). The associated flooding elevations were closer to design levels in most locations, on the order of 100-year flood events. Flow velocities were high, and debris accumulation contributed to flooding extending beyond creek and riverine banks (Wright Water Engineers, Inc. 2014). Figure 2 shows the percent of normal rainfall over Colorado and surrounding states from September 10-16, 2013.

Recent natural disasters and the mountainous terrain increased the impact of the rainfall on the affected areas. Three years prior, a wildfire burned 6,000 acres in Fourmile Canyon. Members of the Boulder Office of Emergency Management (OEM) cited this fire as a contributing factor to the severe flooding experienced in the county. The Fourmile Canyon fire was one of the most damaging wildfires in Colorado history, destroying 168 homes and costing an estimated \$220 million in insured losses (Graham et al. 2012). After a wildfire, the absorbent organic material in the upper layers of the soil is burned off, and the soil becomes more hydrophobic. With much of the vegetation removed, particularly the trees with their large canopies, the ability of the natural landscape to absorb rainfall was significantly decreased. Furthermore, the rapid elevation drop from an elevation of approximately 2,500 meters (8,228 ft.) west of Boulder (elevation of Nederland) to the base of the foothills at an elevation of approximately 1,500 meters (4,984 ft.) (elevation of Longmont) increased the flow velocity of water, often carrying debris and causing severe erosion throughout. The flood velocity, bank erosion, and accumulation of debris resulted in portions of creeks changing course. 


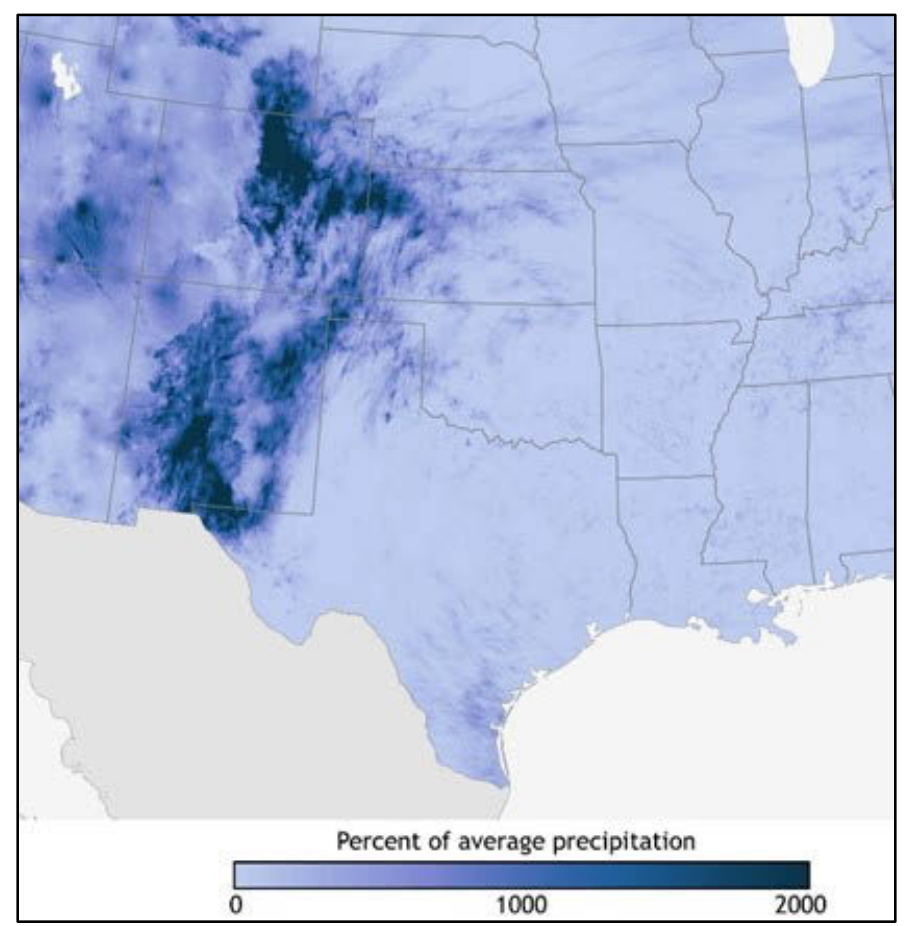

Source: Scott (2013).

Figure 2. Percent of Normal Rainfall over Colorado and Surrounding States from September 10-16, 2013

The extreme rainfall resulted in emergency responses statewide. On September 12, Governor Hickenlooper declared a state of emergency in Boulder and 17 other counties. On September 15, President Obama declared States of Emergency in Boulder, El Paso, and Larimer counties, followed by 12 other counties on September 16 (see Figure 3). This declaration made Federal aid and resources available to state and local authorities in the affected areas. 


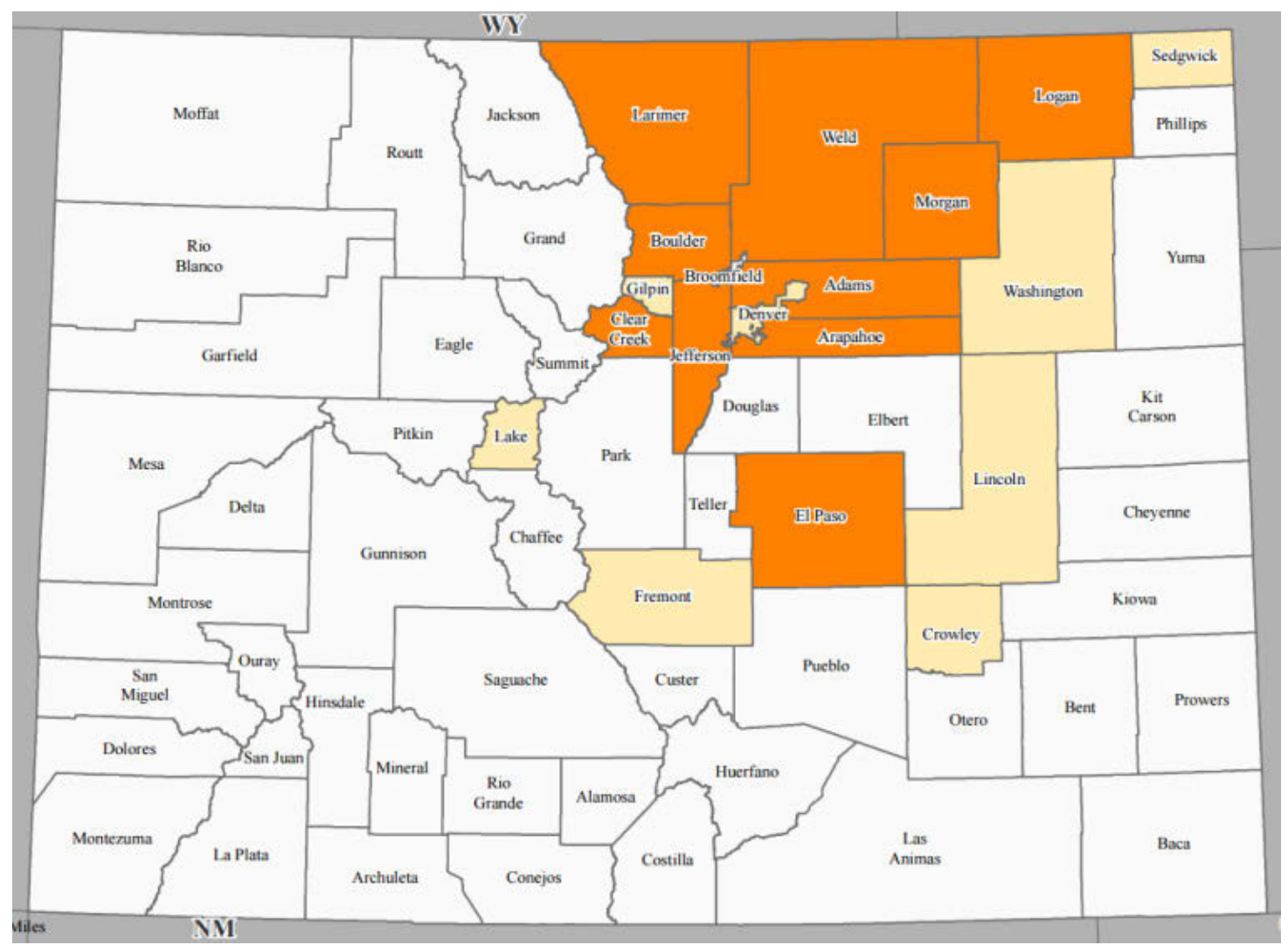

Source: Federal Emergency Management Agency (2013).

Note: Counties in orange were designated Individual Assistance and Public Assistance counties, while counties in brown were deemed Public Assistance Only counties.

Figure 3. Colorado Disaster Declaration as of October 21, 2013

\section{B. Community Impacts}

\section{Boulder County}

The flooding event of 2013 was exacerbated by the high degree of soil saturation, high velocity flows, and large amounts of debris and boulders carried by the streams and rivers. Water exiting the foothills diverted into nearby rivers, including the St. Vrain, Fourmile Creek, and others. ${ }^{2}$ The velocity and high flowrates enabled flood waters to cut new courses outside of original waterway banks. Bridges, roads, and public and private properties were eroded, washed away, or covered in debris. Immediately after the flood, access to many homes was denied, and debris accumulated in many of the waterways (Boulder County 2015).

2 Left Hand Creek, Boulder Creek, South Boulder Creek, Little Thompson River, Fourmile Canyon Creek, and Gold Run Creek. 
The volume of water carried by the St. Vrain Creek was over 15 times its normal amount by the evening of September $11 .{ }^{3}$ Debris accumulation formed temporary dams, causing the St. Vrain to change its course. As a result, the town of Lyons was cut off from other communities and lost all utility services. The overflow of the St. Vrain Creek also affected the city of Longmont, damaging the city's water storage and delivery system, along with bridges and critical infrastructure. The mountain communities faced extensive damage as rivers and creeks cut new courses and scoured the mountainside. The town of Jamestown lost more than 50 percent of its infrastructure (including roads, bridges and a water plant). More than 1,000 residents were evacuated from Lyons, Jamestown, and other mountain communities. Every road going west in Boulder County, with the exception of Sunshine Canyon (which sits on a ridge), was washed out to the point that major repairs or replacement was necessary. In total, the county lost 40 to 50 bridges and structures (Boulder County 2015).

Federal Emergency Management Agency (FEMA) Verified Flood Loss data show over 11,860 housing units damaged by the floods across the county. Of these, 445 were determined to have suffered major-to-severe damage. The county Department of Transportation recorded that over 200 properties had lost access to homes as a result of damage to bridges, culverts, or private access roads (Boulder County 2015).

\section{City of Boulder}

The rainfall and subsequent flooding event in the Front Range dropped historic levels of rainfall within and around the City of Boulder. Some areas within or near the city received rainfall totaling 410 to $510 \mathrm{~mm}$. (16 to 20 inches) during the 1 -week period from September 9 to September 16, 2013. This rainfall event set a new 24-hour rainfall record of $231 \mathrm{~mm}$. (9.08 inches), which exceeded the previous record of $122 \mathrm{~mm}$ (4.80 inches) set in 1919 (National Weather Service 2014).

Within the City of Boulder, eight watersheds comprise the larger Boulder Creek drainage basin: South Boulder Creek, Bear Canyon Creek, Skunk Creek, Gregory Canyon Creek, Boulder Creek, Goose and Twomile Canyon Creeks, Wonderland Creek, and Fourmile Canyon Creek. Across these watersheds, the combined effects of high precipitation amounts, peak flows, and associated flooding resulted in different flooding conditions across the city's watersheds. Peak flow rates, which are used to establish the 100-year event design criteria for engineered stormwater systems, generally did not approach or exceed an equivalent 100-year-event flow rate for most of the watersheds in the City of Boulder. Only parts of three watersheds experienced peak flows that approached

3 Based upon Kimbrough and Holmes 2015, the Lyons streamgage recorded over 1,500 cfs before it was destroyed during the late hours of September 11, 2013. The mean monthly discharge for September for this streamgage is $94 \mathrm{cfs}$ based upon the streamgage data collected from 1977-2013 (USGS Streamgage 06725450). 
or exceeded the 100-year-event flow rate. Boulder Creek experienced a 50- to 100-plusyear-event flow rate; Twomile Canyon Creek experienced a 100-plus-year-event flow rate; and Fourmile Canyon Creek nearly experienced a 100-year-event flow rate. The remaining watersheds within the limits of the City of Boulder experienced peak flows less than or equivalent to a 25- to 50-year event (Wright Water Engineers 2014).

While peak flow rates for most of the system were below the design storm event, the relatively long duration of the rainfall event, the intensity of rainfall and associated high volumes of water, and the high debris loads resulted in flooding impacts greater than would be expected for a flood with observed flow rates. Boulder's primary hazard of concern is flash flooding, which is the hazard profile that much of the stormwater infrastructure is designed to handle. The long duration rainfall and associated high volumes of water led to soil saturation within the watersheds and significant sediment transport and debris flows. The high levels of sediment and debris entrained by the stormwater affected the structure of the creeks, resulting in a reduction in conveyance capacity in some reaches of the waterways. In some areas of the city, particularly in areas within the watersheds of Goose and Twomile Canyon Creeks and Skunk Creek and its tributaries, overland flow in urban areas exceeded the effective 100- and 500-year floodplain extents. Areas around South Boulder Creek experienced urban flooding within the creek floodplain. The flooding met or exceeded the effective 100-year floodplain in many locations. Other locations, such as Boulder Creek, where engineered stormwater systems exist, urban flooding was experienced within the creek and floodplain but did not meet or exceed the effective 100year floodplain extents (Wright Water Engineers 2014). The map in Figure 4 indicates the extent of urban flooding experienced during the 2013 flood event compared to 100- and 500 -year floodplains.

\section{Towns of Lyons and Jamestown}

The town of Lyons began to flood on September 12, 2013, three days after the rain began. Within the first days of the flooding, Lyons lost power, telephone service, potable water, and access to neighboring towns.

On September 12, residents in low-lying parts of town were advised to retreat to higher ground after a warning that a dam near Pinewood Springs had failed (Young 2013). The National Guard began evacuating the most vulnerable residents on September 12 and other residents on September 13 via temporary roads and airlift (Town of Lyons 2014). These efforts included over 3,000 animal evacuations. LifeBridge Christian Church (Longmont, Colorado) set up an evacuation center for displaced residents. Immediately after the flooding began, the county offered assistance through its Office of Emergency Management. 


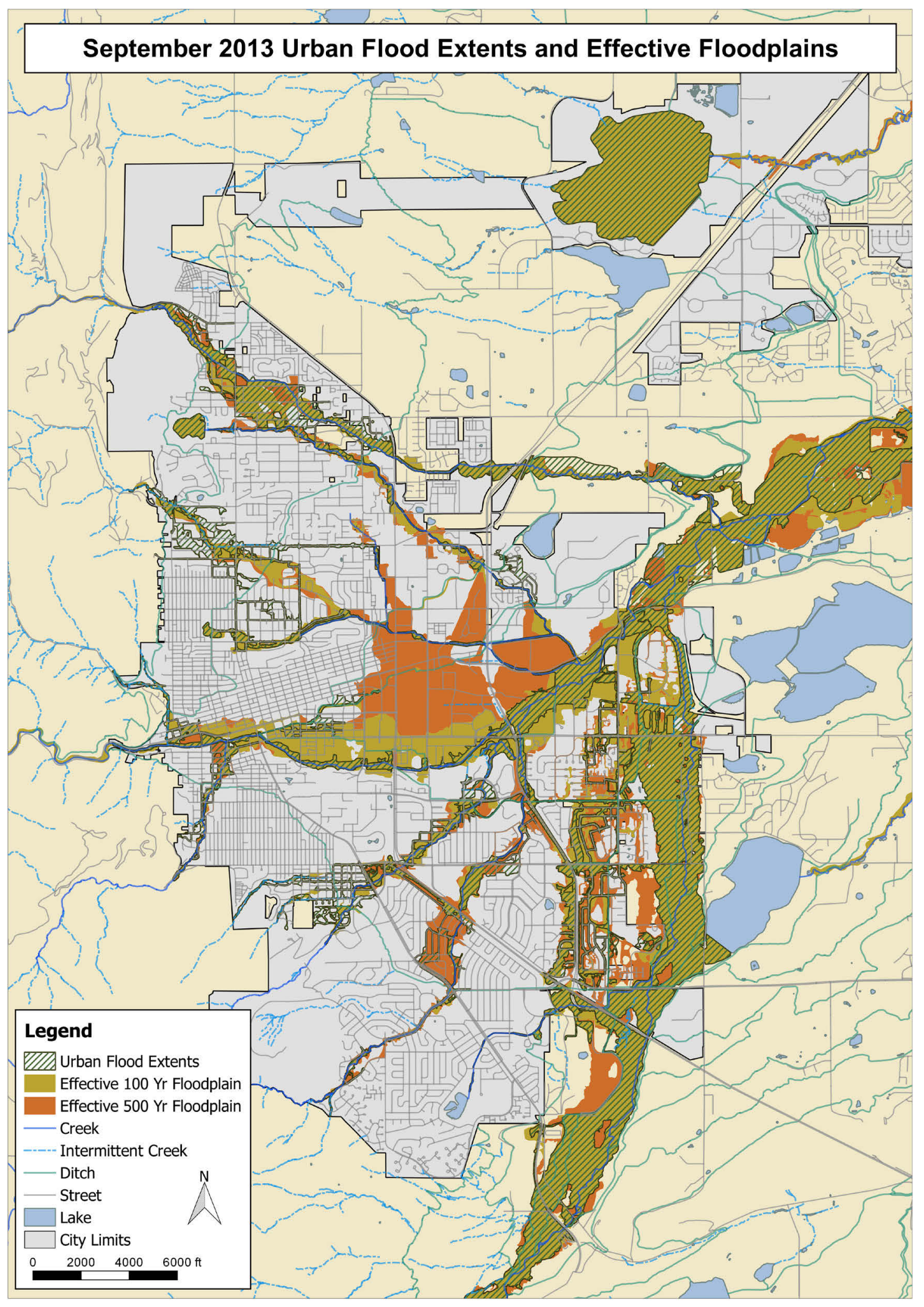

Source: Reproduced using City of Boulder GIS data, based on Wright Water Engineers (2014), Appendix B.

Figure 4. City of Boulder September 2013 Urban Flood Extent and Effective Floodplains 
The 2013 flood devastated the town of Jamestown. Thirty-five percent of residences were severely damaged, 13 percent were destroyed or damaged beyond repair, the fire department and half of the town roads were destroyed, a main county access road was severely damaged (Route 94), and the town's water treatment facility and half of the water distribution network were destroyed (Town of Jamestown 2015b). The Little James Creek and James Creek left their natural channels and formed new channels, which caused significant erosion and undercut roads and homes in the process (Town of Jamestown 2015a). Key cultural resources, such as the Post Office and a church, were damaged, and the Town Square Park was destroyed. Infrastructure losses alone were estimated at \$20 million. The town's Elysian Park suffered significant damage. Toxic mine tailing waste leaked into the James Creek waterway. As a result of this damage, 90 percent of residents were evacuated after the flood (Town of Jamestown 2016d).

After the restoration of water utilities and temporary repair of roads in 2014, residents were able to return and rebuild their homes. By the end of 2014, 94 percent of homes were occupied, and, by the end of 2015, 98 percent of homes were occupied (Town of Jamestown 2016d). 


\section{Case Study 1: Boulder County}

\section{A. Pre-Flood Preparedness}

\section{Recovery Structure Established Following the Fourmile Canyon Fire}

Boulder County utilized its extensive recovery experience it garnered from the 2010 Fourmile Canyon Fire where 165 homes were destroyed and applied it to the 2013 Flood. After the 2010 Fourmile Canyon Fire, the fire chiefs of the affected communities noted that a single point person was needed during the recovery period to coordinate outreach with residents and better understand barriers to recovery. The role of Recovery Manager was assumed by an employee of the Boulder County Department of Land Use, who held the job for 2 years. The role was created with community engagement in mind, but the primary responsibility of the Recovery Manager was to coordinate county department efforts during recovery from the fire. The experience of establishing a Recovery Manager after the Fourmile Canyon fire provided early recovery-phase planning before the 2013 flood event. Additional information about the implementation, roles and responsibilities of the flood recovery structure are discussed in the immediate post-event section.

\section{Emergency Management Coordination and Governance Structure}

The Boulder County OEM and the county-wide Emergency Operations Center (EOC) reside within the county sheriff's office. Boulder County's OEM serves all incorporated municipalities and unincorporated areas within the county. The OEM is the central planning element for hazard response and management and conducts training exercises to ensure readiness in the event of a disaster. The responsibilities and roles of the OEM are codified within FEMA's National Planning System.

The EOC was used during the 2010 Fourmile Canyon Fire and later in the 2013 flood event. The OEM has operated a Type-3 Incident Command Team since June 2009, which allows personnel from different municipal jurisdictions and the state to coordinate response operations. This operational structure has proven effective in the county. During the Fourmile Canyon Fire, the OEM was able to deploy emergency response vehicles from several Boulder County jurisdictions to evacuate over 3,000 residents and prevent any loss of life and injury. 


\section{B. Emergency Response and Short-Term Recovery Actions and Decisions}

\section{Context and Over-Arching Considerations during the Immediate Response}

On September 12, 2013, the governor declared a state of emergency once the scale and magnitude of the event had become apparent. The Boulder County OEM activated the EOC. The county's immediate and short-term goals were to evacuate those in danger, ensure the safety of its citizens, assess damage, and address those situations that might imminently lead to further damage.

While a large number of decisions that were made during the days after the flood related to immediate protection of life and property, the focus in this chapter is on actions that were necessary for restore public and private infrastructure and ensure public safety.

\section{Governance Structure for Emergency Response Actions and Decisions}

In the days following the event, a multi-departmental Flood Recovery Policy Team was formed. The team consisted of the County's Board of Commissioners, county departmental leads, and the county Flood Recovery Manager and served as the main coordination and decision-making group for the entire county in the weeks following the flood. (It should be noted that Boulder County does not have a County Manager function.) The Flood Recovery Policy Team's roles included:

- Lead the development of the community's recovery plans and ensure that they are publicly supported, actionable and feasible based on available funding and capacity.

- Make high-level business decisions for stabilization and recovery projects, especially those related to policy and with cross-organization impact.

- Responsible for execution of county Board of Commissioners' directives.

- Identify any program-level issues pertaining to their projects and reporting the issue to the Program Manager as soon as possible.

- Advise on changes to scope, schedule, budget, policy and regulatory action to the Board of Commissioners.

- Resolve strategic, policy and project issues escalated by the project teams.

- Communicate with other key stakeholders; involve the public information officer as necessary.

The Flood Recovery Policy Team began meeting daily during the flood, even before the emergency response had ended. This was one of the key lessons learned from the fire, not to wait to begin the recovery efforts. Over time as the recovery progressed the meetings 
shifted to weekly, bi-weekly and then monthly. The team's decision-making capacity continued through the midterm and long-term recovery period. As of 2017, the team continues to meet on a monthly basis to track recovery activities and perform recovery functions as subsequent disaster events take place (e.g., wildfires).

Policy decisions specifically regarding the unincorporated county were made and prioritized through recommendations from the county department heads and the Flood Recovery Manager, with approval from the Board of Commissioners. Some of the approvals were granted after a formal commission hearing, but many approvals were expedited. One of the lessons learned from the recovery process was that the requirements of a formal approval process created delays when fast-paced decision-making is required after a disaster. As a result, the county passed resolutions that granted temporary approval authority to department heads in the case of a declared emergency. This temporary solution is now codified in Article 19 of the Boulder County land-use code (Boulder County 2013). ${ }^{4}$

\section{Establishment of County Recovery Leadership Group}

Given the magnitude of the flood it became apparent that the county needed to assign several leadership roles whereas with the Fourmile Canyon Fire there was one primary recovery leadership role. These roles were responsible for implementation of policies established and decisions made by county leadership. The county created three positions with the following responsibilities:

1. Intergovernmental Relations: Deputy to the Commissioners

a. Represent and speak on behalf of the Commissioners.

b. Intergovernmental Relations - negotiates agreements (municipalities, State, Federal, partners) and provides information about the jurisdiction's activities to those outside the organization.

c. Captures, coordinates and communicates FEMA and State of Colorado guidance, policy and information sharing.

d. Communicates and coordinates Boulder County stabilization and recovery needs with Federal and State delegations.

2. Community Engagement and Coordination: Flood Recovery Manager

a. Overall stabilization and recovery coordination.

4 Boulder County Land Use Code Article 19 was amended by Boulder County's Board of County Commissioners in October 2013 to amend Article 19-100.F related to the Fourmile Canyon Fire recovery process, extending the timeline for rebuilding, and creating Article 19-200 as an interim permitting process for the 2013 extreme rainfall and flood event. 
b. Responsible for community engagement; organize, coordinate and advance the approved stabilization and recovery activities.

c. Community Ambassador - connect communities to County resources; community point of contact.

d. Collaborate with staff to assess community needs and advocate for community services and support; provides community with information and consistent messaging in collaboration with the public information officer.

3. Flood Stabilization \& Recovery: Director, Office of Emergency Management

a. Connection to law enforcement (security, site access control, public safety).

b. Coordinates emergency preparedness, life safety and protective action.

c. Responsible for stabilization resource coordination (Federal, State).

d. Short-term (initial 6 months after the event) coordination and communication of FEMA guidance, policy, and information sharing for Public Assistance Categories A (Debris Removal) and B (Emergency Protective Measures).

The Flood Recovery Manager represented a key coordination role across multiple departments and policy makers. This position required: (1) coordinating the recovery for all of the different departments within the organization, (2) serving as the primary point of contact for community members, and (3) act as an advocate for community members for services and support as well as for policy changes, when necessary. The manager met frequently with community members, totaling over 60 meetings with 2,000 community members. The community outreach meetings served as a forum to listen to community member concerns, understand the needs of community members, and share updates about projects and resources and services. The Recovery Manager is housed in the Commissioner's office rather than OEM in order to facilitate direct access to the commissioners and all of the department heads, given that the county does not have a county manager.

\section{Infrastructure Recovery Actions and Decisions}

County services for unincorporated areas are land-use planning, transportation, creek and watershed management, parks and open space management, and public health services. Within the unincorporated areas of the county, water and wastewater services, access roads right-of-way and maintenance, and culvert management are not public services.

\section{a. Damage assessments}

One of the first actions taken by Boulder County after the flood was to conduct damage assessments. Planners in the Department of Land Use partnered with staff from 
the International Code Council to provide guidance and conduct assessments. At this time, several assessments were being conducted by different groups, which lead to challenges in maintaining consistency across multiple assessors. Some of the challenges included reconciling conflicting accounts of damage and ensuring that properties and lots were correctly identified. ${ }^{5}$

The Parks and Open Spaces Department also conducted damage assessments in the county open spaces in the days after the flood. Because of the damage to roads, paths, and trails, county employees traversed the banks of the St. Vrain Creek on foot, using Global Positioning System (GPS) devices to record their locations when assessing damage.

\section{b. Emergency support and construction of access roads}

The Transportation Department played a key role in the initial emergency response coordinated by the OEM. In the days following the flood, the Transportation Department moved people to shelters using fleets of school buses organized under pre-existing agreements.

To access isolated areas, the Transportation Department made decisions regarding which roads to close and which to keep open and where to build temporary roads for access. Immediately after flooding subsided, road maintenance crews and emergency contractors began building temporary dirt roads in locations that were inaccessible (i.e., steep canyons with significant erosion and flood damage) where emergency officials required access.

\section{c. Expanded Land Use Department authorities: Temporary rebuilding moratorium and emergency repair permits}

The Land Use Department instituted a moratorium on issuing building permits to reduce risk to citizens while infrastructure and public services were restored. Before the flood, any change in land-use regulations had to be approved by the Board of Commissioners before it could be enforced. Since the flood, the Board of Commissioners approved a change to Article 19-100 of the Boulder County emergency procedures and training, which has provided the Director of Land Use the authority to place a moratorium on building permits for up to 30 days without procuring prior approval from the commissioners. After the 30-day period, the commissioners can either lift the temporary ban or extend it (Boulder County Land Use Department 2014).

The same provision (Article 19-100 of the Boulder County emergency procedures) authorizes the Director of Land Use to issue temporary emergency repair permits without prior approval from the county commissioners. Examples include repairs to prevent further water damage, temporary stabilization to shore up structures, temporary stabilization

5 The department now uses Crisis Track (https://www.crisistrack.com/), based on Google maps, which uses GIS to correlate damage with the location. 
involving earthwork to avoid imminent collapse of structures or property, and temporary restoration of public recreational facilities, such as trails and trailhead parking areas.

\section{Actions and Decisions Related to Community Needs}

\section{a. Implementation of Emergency Support Functions (ESFs)}

The county government prioritized sheltering displaced residents and assisting with evacuation after the flood. The Department of Housing and Human Services (HHS) led an operations center with the Department of Public Health and Department of Community Services to activate the following ESFs:

- Mass Care, Emergency Assistance, Temporary Housing, and Human Services;

- Public Health and Medical Services; and

- Volunteer and Donations Management (Support Annex) ${ }^{6}$.

\section{b. Support for residents applying for and receiving FEMA individual assistance}

Since the flood event was designated a disaster through a presidential disaster declaration, representatives from FEMA were actively involved in supporting emergency response operations, providing resources, and identifying qualified personnel to assess damage and begin providing resources for restoration activities. For this event, FEMA individual assistance in the response phase was made available in the form of (1) hotel vouchers, rental assistance, and other support for homeowners who were temporarily displaced and (2) direct assistance to homeowners for repairs to damaged property. FEMA representatives conducted assessments of damaged properties and directly paid sums for damage that qualified per FEMA guidelines.

While FEMA representatives worked directly with the affected homeowners, Boulder County HHS provided case management and administrative support to guide county residents through the process of accessing support for all their qualifying needs. Boulder County HHS took a lead role in providing resources or support to address gaps in resident needs that were not met by another organization. For example, when landlords who rented out basement apartments claimed renters as tenants covered by their homeowners or flood insurance, this prevented the tenant from applying for his/her own coverage. In these instances, Boulder County HHS planned to provide rental assistance for the tenant. The department subsequently did not need to access internal resources to provide rental assistance as the Community Development Block Grant Disaster Recovery (CDBG-DR) grants served this purpose.

6 This is a Colorado-specific support annex that is separate from the Emergency Support Functions. 


\section{Summary of Emergency Response Actions and Decisions}

\section{a. Infrastructure actions and decisions}

- Repaired roads: Immediately after the flooding subsided, road maintenance crews and emergency contractors began building temporary dirt roads in locations that were otherwise inaccessible. County officials prioritized temporary road restoration in locations where emergency management and public safety officials required access.

- Assessed damage: Planners in the Land Use Department partnered with staff from the International Code Council to conduct damage assessments. Several groups, including the National Guard, supported damage assessment activities, which created a challenge for county officials to maintain consistency across assessment and data collection activities.

- Enforced a moratorium on issuing building permits: County commissioners approved and the Land Use Department instituted a moratorium on issuing building permits for 30 days after the flood. This emergency moratorium was implemented to reduce risks to citizens while infrastructure and public services were being restored and to ensure that rebuilt structures met county building codes. The provision also provided the Director of Land Use the authority to issue emergency permits to prevent imminent collapse or damage of structures or property.

\section{b. Actions and decisions to meet community needs}

- Established Emergency Shelters and Public Services: The Boulder County HHS established emergency shelters and coordinated with the Department of Transportation to use the county's school bus contractors to provide emergency transportation to those shelters. At the shelters, the Boulder County HHS and Department of Public Health and Community Services Department activated ESF 6 (Mass Care, Emergency Assistance, Temporary Housing, and Human Services) and ESF 8 (Public Health and Medical Services), and provided Volunteer and Donations Management support.

- Provided administrative support for FEMA individual assistance: Boulder County HHS provided case management services and administrative support to county residents who were applying to FEMA for individual assistance for temporary housing, rental assistance, and home repair funding. 


\section{Midterm Recovery Actions and Decisions}

\section{Context and Considerations for Midterm Recovery Efforts}

Many of the decisions made by Boulder County officials in the months after the flood addressed the difficulties arising from the changes caused within and beyond the pre-event floodplain. For example, some county residents took steps to protect their property by building diversion structures to redirect water, which sometimes inadvertently redirected water onto other properties. Others tried to compensate for the loss of access roads and bridges by installing rocks and culverts in the new channel to provide access to their houses. Recognizing that these individual actions may have adverse consequences for neighboring properties, the county undertook a comprehensive waterway restoration effort in collaboration with homeowners.

Another primary motivating factor for Boulder County officials was the spring snowmelt runoff that usually takes place in March and April. Without restoration, creek and river levels and flows would continue to damage vulnerable locations. The implications of the spring runoff were an important consideration for the county's transportation infrastructure because much of the road network is located along the creeks and rivers.

\section{Infrastructure Recovery Actions and Decisions}

Many of the infrastructure recovery decisions made in this time frame addressed methods to achieve temporary recovery of functionality. Longer term goals for resilience of repaired and reengineered transportation infrastructure system components were considered by planning system recovery around the altered terrain and flood zones of the region.

\section{a. Remapping of waterways and floodplain}

In response to changes in the waterways and flood-impacted watersheds in Boulder County, the Colorado State Legislature funded the Colorado Water Conservation Board to update floodplain maps (Colorado Water Conservation Board 2017). Floodplain mapping updates inform future land-use and infrastructure planning activities and also guide flood recovery. These updates are ongoing, as of early 2017. Interim floodplain maps, while currently not enforceable for regulatory purposes, were approved by FEMA to be used as "best available data" and are currently being used by the county for information and guidance. Updated maps are in the process of being adopted for regulatory purposes (Jones, Piertramali, and Ross 2014). As of July 2016, Boulder County is considering regulatory flood code revisions that recognize floodplain maps that have been produced by the county but have not yet been adopted by FEMA as the Flood Insurance Rate Map (Boulder County Transportation Department 2016). 


\section{b. Temporary permitting processes for rebuilding on the floodplain}

After the moratorium on rebuilding was lifted, temporary permitting processes were developed by the Land Use Department to ensure that all building activity conform county building codes and standards, including the Hazard Mitigation Review process adopted after the flood (see subsection 3.C.2.d).

In the months after the flood, the Land Use Department issued temporary emergency permits with limited scope to authorize work necessary to prevent imminent unsafe conditions (Boulder County Land Use Department 2013). Temporary emergency permits were issued for the following:

- Structure stabilization, including foundation, piers, walls, floors, and so forth;

- Bank stabilization to protect structures from further erosion (not including work that required authorization from the U.S. Army Corps of Engineers) (Williamson 2013);

- Retaining or protective walls; and

- Roof and siding protection.

\section{c. Collaborative planning for waterway and road network restoration}

Property owners along the creeks and rivers in Boulder County were severely affected by the 2013 event, not just by the flooding, but also by the accumulation of debris in and along the creeks, and damage from boulders carried by the flood waters. County officials noted that after the event, they took whatever measures they could to make properties accessible and habitable. These measures included using heavy equipment to divert stream water away from properties, which occasionally inadvertently changed the natural course of the creeks.

Recognizing that any action taken in the creeks has upstream and downstream impacts, the county sought to engage homeowners in a discussion about the damage and about the rebuilding process using aerial photos to facilitate the discussion. A resident coalition was created for each of five watersheds. A Comprehensive Creek Planning Initiative was put in place in early spring 2014 as a collaborative effort with multistakeholder coalitions and public engagement. The Transportation Department established a watershed group that worked with the resident coalitions to develop restoration plans for the five creeks. This group was set up as a county initiative with State and Federal funding.

For the restoration of the county's road network, the Department of Transportation prioritized efforts to repair road infrastructure before the spring runoff began. County engineers recognized that improving the resilience of the transportation road network would also require improvements to collocated waterways. The Transportation Department is responsible for coordinating the restoration of the roads and the waterways. 
In places where waterways were significantly altered, engineering design considerations involved tradeoffs between preserving the road design and incorporating sufficient conveyance capacity for future flood flows. For example, in Left Hand Canyon, the county implemented a compromise solution by excavating additional space to expose bedrock. This action had the benefit of providing more space for the creek and ensuring that at least one lane of the road was on bedrock. In other places, residents resisted the idea of excavating the mountainside, which created an engineering challenge for the restoration of the creeks and roads. An ongoing challenge for the county engineers has been to coordinate the redesign of the roads and creeks while balancing the county residents' desire to leave the creek systems as unaltered as possible.

\section{d. Standards and code changes: Implementation of a Hazard Mitigation Review process}

A Hazard Mitigation Review is a temporary permitting process to allow for the safe rebuilding of destroyed or severely damaged structures. The regulations allow flexibility for structures to be rebuilt at a lower risk location in accordance with the county's Floodplain Development regulations:

"Hazard Mitigation Review applies to rebuilding or restoring structures damaged or destroyed by the 2013 Flood, whether by flooding, debris flows, mudslides, slope instability, drainage channel shifts, area drainage system impairments or failures, soil saturation, or related hazards. Hazard Mitigation Review shall also apply to any work for which a County grading permit for earthwork between 50-500 cubic yards, and/or a floodplain development permit is required to repair or restore property damaged by the 2013 Extreme Rain and Flood Event and its associated natural forces." (Boulder County 2016e).

The Hazard Mitigation Review process was adopted as an interim Land Use code change regulation (Boulder County Land Use Department 2014 - see Boulder County Land Use Code Article 19, "Procedures Following Disasters," 19-300 C, "Hazard Mitigation Review Process," 19-9) that was approved by the County Board of Commissioners in October 2013, a month after the flood. The purpose of the Hazard Mitigation Review was to allow the county to:

Assess the safety of the proposed restoration/construction in light of the actual damage caused by the 2013 Extreme Rain and Flood Event and related hazardous forces triggered by that disaster (such as flooding, debris flows, rockfalls, mudslides, topographic changes or instability, drainage channel shifts, area drainage system impairments or failures, and soil saturation), to the Eligible Structure, the subject property, surrounding properties, and public and private infrastructure serving the subject property (Boulder County Land Use Department 2014, 19-10). 
The Hazard Mitigation Review process was conducted for a large number of residential structures in Boulder County. The Director of the Land Use Department implemented the Hazard Mitigation Review as a best practice for quickly enabling resilient rebuilding goals.

\section{Actions and Decisions Related to Community Needs}

In the months following the event, temporary emergency permitting processes mandated that repair and rebuilding of flood damaged structures (in and outside the original floodplain) had to undergo a Hazard Mitigation Review and obtain all necessary floodplain-related permits. Flood-affected homeowners in Boulder County were therefore negotiating the review and permitting processes necessary to get repairs started and multiple avenues of Federal and local funding for assistance or reimbursement of repair expenses.

The Boulder County HHS served as the county's lead agency to provide comprehensive administrative support, including case managers, eligibility specialists, housing and financial advisors, to help homeowners navigate the multiple permitting and application processes.

\section{a. Meeting Immediate Community Needs through Disaster Assistance Centers (DACs)}

A decision was made by the Flood Policy Team to open DACs. The DAC sites were set up in Longmont (larger site) and Boulder (smaller site). Boulder County HHS provided case management for the flood victims who came to the DACs. Boulder County HHS also maintained a "DAC-in-a-box," which was an easily transportable, mobile unit that allowed Boulder County HHS to provide basic goods and services to the mountain communities. The DACs were intended to address immediate community needs and were only open for 2-3 weeks after the flood.

\section{b. End-to-end case management for damage repair and reimbursement}

Boulder County HHS assigned case managers to flood-affected homeowners. These staff had end-to-end ownership of each case, from determining eligibility and needs to ensuring that the property was safe, accessible, and habitable before the residents could move back into it. Boulder County HHS created a single application for the different types of home damage ${ }^{7}$ to help residents determine their options and the funding for which they were qualified. Case managers were supported by a range of specialists, including eligibility specialists, home access coordinators (who provided assistance with access permitting and repair), rehabilitation coordinators (who assisted with work inside the

7 Rehabilitation and repair, home access, and temporary rent assistance. 
property and structures around the house, such as septic tanks, and ensured that the property was habitable), and housing and financial advisors. Boulder County HHS specialists worked closely with county land-use planners, floodplain administrators, and public health officials to coordinate and centralize the management of each case.

In addition to providing support with obtaining reimbursements from FEMA, the county administration was responsible for supporting residents in navigating the multiple avenues of Federal assistance and grant funding available. For those county residents who did not qualify for FEMA funding or for whom FEMA assistance did not fully cover the damage and for those whose properties were outside the floodplain, the county applied for Community Development Block Grant Disaster Recovery funding.

\section{c. Establishing a Flood Rebuilding Permit and Resource Center}

The Department of Land Use established a Flood Rebuilding Permit and Resource Center to offer a single point of service for permitting and rebuilding requirements for damaged structures, including septic tank permits and access permits. The Center included officials from the Departments of Transportation and Public Health, permitting officials from the Department of Land Use, county finance department staff, Town of Jamestown staff, and private sector infrastructure experts and consultants. The Flood Rebuilding Permit and Resource Center existed as a separate office for a short period ( 2 to 3 months) before it was integrated into a consolidated Flood Recovery Center.

\section{Summary of Midterm Actions and Decisions}

\section{a. Infrastructure actions and decisions}

- Remapped floodplain: The Colorado State Legislature funded the Colorado Water Conservation Board to update the floodplain maps for Boulder County. Some floodplain maps created before the 2013 flood were out of date due to waterways exceeding historical floodplain extents. Interim floodplain maps were used by the county for information and guidance. As of July 2016, updated maps are currently in the process of being adopted for regulatory purposes.

- Provided temporary permitting: After the moratorium on rebuilding was lifted, temporary permitting processes were developed by the Department of Land Use to ensure that all rebuilding activity conformed to county building codes and standards. These temporary permits were issued for structure stabilization, bank stabilization, retention/protective walls, and roof and siding protection.

- Established creek resident coalitions for collaborative planning of creek restoration: The county sought to engage homeowners living along waterways 
in a discussion about the damage and the rebuilding process. Resident coalitions were created for each of the five watersheds and a Comprehensive Creek Planning Initiative was started in early spring 2014 as a collaborative effort with multi-stakeholder coalitions and public engagement.

- Planned coordinated temporary repair of roads and creeks in the watersheds: County engineers recognized the importance of the waterways located alongside the damaged roads; therefore, in places where waterways were significantly altered, engineering designs deliberately incorporated tradeoffs between road design and sufficient conveyance capacity for future flood flows.

\section{b. Actions and decisions to meet community needs}

- Opened DACs, Flood Rebuilding Permit and Resource Center, and Flood Recovery Center: The county, in collaboration with the cities of Boulder and Longmont, opened two DACs to serve immediate locations where they could access resources and assistance. The Land Use Department opened a Flood Rebuilding and Permit Center as an office where residents could obtain information and applications for permitting and rebuilding. The county ultimately opened a Flood Recovery Center that served as a central location where multiple county services were provided, coordination between multiple jurisdictions, and private sector consultants took place.

- Provided case management services for flood affected homeowners:

Affected property owners were assigned case managers who had end-to-end ownership of each case, from determining eligibility and needs to ensuring that the property was safe, accessible, and habitable before the residents could move back into it.

\section{Long-Term Recovery Actions and Decisions}

\section{Context and Considerations for Long-Term Recovery Efforts}

Many of the decisions made for long-term recovery address complex issues wherein the county sought to reduce risk while balancing future development opportunities and the cost of more stringent regulatory compliance.

Boulder County participates in FEMA's National Flood Insurance Program (NFIP) and maintains a current community rating of 5 (Federal Emergency Management Agency 2016d). This rating is maintained through the enforcement of regulations that require the implementation of design standards requiring structures be designed and constructed above 
the advisory base flood elevation and flood proofing for houses on the floodplain. ${ }^{8}$ Despite these mitigation actions, when the 2013 flood occurred, significant damage occurred outside the 100-year floodplain due to a number of factors (see section 2.A and 2.B for discussion of the hydrometeorological event). In addition, the mandated flood-proofing measures were insufficient to prevent damage caused by boulders and debris carried by the flooding creeks.

Due to the severe nature and extent of flood damage in Boulder County, questions remain as to the adequacy of current floodplain regulations to avoid future losses. Updates to floodplain maps are currently ongoing in early 2017 to ensure future floodplain maps accurately represent local flooding risk (Colorado Water Conservation Board 2017). Discussions on long-term recovery among county officials have explored opportunities for reducing future risks and adopting new flood regulations applicable to the local geography, while balancing community economic and cultural considerations.

\section{Governance Structure for Long-Term Recovery Actions and Decisions}

Local non-profit organizations and local governments formed a Long-Term Flood Recovery Group (LTFRG) to facilitate the identification of unmet meets from county residents and businesses and facilitate the distribution of donated funds. The LTFRG is composed of county officials focused on case management, with direct involvement from local contractors and businesses, volunteer organizations, and other local non-profit organizations. Long-term recovery government functions for permitting, regulatory actions, and infrastructure restoration activities fall within standard non-emergency department roles within each jurisdiction.

\section{Infrastructure Restoration Actions and Decisions}

The county's long-term view focused on increasing resilience throughout the region. By implementing new regulations and restoration programs, the county hoped to address vulnerabilities in the built infrastructure systems and to prepare for future events.

\section{a. Enforcing floodplain compliance on a much expanded flood hazard zone}

Boulder County's Department of Land Use was the lead agency in making the "substantial damage" determination for every house on the floodplain and engaging with FEMA for repair assistance under NFIP. ${ }^{9}$ The county made the decision to enforce floodplain regulations per the new (interim) floodplain maps being developed by the

8 Boulder County maintains a Community Rating System (CRS) rating of 5 (Boulder County 2016c).

9 A structure is considered substantially damaged when the cost of restoring the structure is equal to or exceeds 50 percent of the pre-damage value of the structure. 
Colorado Water Conservation Board, which are expected to bring thousands of additional properties into the floodplain.

NFIP regulations specify that substantial improvements of existing buildings (remodeling, rehabilitation, improvements, or additions) or buildings that have sustained substantial damage must be brought into compliance with requirements for new construction. As a result of this regulation and the properties being added to the extended floodplain, the next time property owners in the newly defined floodplain make any substantial changes to their homes, they will have to ensure that the full structure is brought into compliance with floodplain regulations, including elevating the structure to allow for 2 feet of freeboard (i.e., space between the structure and a specific flood level) (Federal Emergency Management Agency 2016a).

For many of the communities, particularly those that include lower income property owners or contain properties that are part of older mountain communities, county officials believe the financial burden of compliance with the regulations may result in some residents opting to relocate instead of rebuilding. Balancing the need for risk reduction through increased regulation with the distributional impact on lower income communities is an issue that is being considered by the County Commissioners and the LTFRG.

\section{b. Implementation of the Comprehensive Creek Recovery Program}

The Comprehensive Creek Planning Initiative, a partnership between Boulder County and a coalition of residents, was formed in early spring 2014. An initial planning phase identified projects to restore and stabilize creek structures (e.g., bank stabilization, channel realignment, debris removal, revegetation, and restoration of low-flow channels). The plans were approved by the County Commissioners in February 2015. The initiative has now moved from the planning effort and has transitioned to the Creek Recovery and Restoration Program, which is continuing the long-term recovery process by seeking funding for the restoration projects and overseeing the implementation of the collaborative effort (Boulder County 2016e).

Despite these plan approvals, watershed restoration projects remain largely unfunded. The Creek Recovery and Restoration Program aims to secure funds to complete the planned repairs. The county (with the Transportation Department as the lead) has been working with the creek restoration coalitions to secure Federal, State, or county funding so that the creek restoration projects coincide with road repairs. The county was also able to secure Natural Resources Conservation Service's Emergency Watershed Protection (EWP) funds (Boulder County 2016d; Boulder County 2016e). ${ }^{10}$ EWP resources were applied to the

10 On January 26, 2016, at the Boulder County Board of County Commissioners (BOCC) held a public hearing to consider a program request to enable Boulder County to act as the "Local Sponsor" of Natural Resources Conservation Service's (NRCS) Emergency Watershed Protection (EWP) program, 
restoration of waterways crossing private property, which required the owner's permission for a project to proceed. The formation of the coalitions was instrumental in acquiring necessary land owner approval for creek repair and restoration projects.

\section{Actions and Decisions Related to Community Needs}

\section{a. Participation in FEMA's Hazard Mitigation Grant Program (HMGP)}

For communities plagued by repeated flooding, FEMA's HMGP provides Federal funds to underwrite a local jurisdiction's property acquisition program (Federal Emergency Management Agency 2016b). The HMGP is authorized under Section 404 of the Stafford Act (Robert T. Stafford Disaster Relief and Emergency Assistance Act, as Amended 2013). Under this program, which is voluntary, the property is acquired by the government, which then demolishes the structure and levels the plot and restricts future development. FEMA covers 75 percent of the cost of the purchase. In unincorporated Boulder County, the remaining 25 percent has been split between CDBG-DR and the State. The properties are acquired at pre-flood value.

The Department of Land Use, which had the lead on making "substantial damage" determination for properties, identified 65 eligible properties for participation in voluntary property acquisition programs. Both the FEMA HMGP and the HUD Community Development Block Grant Disaster Recovery (CDBG-DR) programs provided support to fund property acquisitions. As of early 2017, 19 properties eligible under the HMGP guidelines are being processed through that program, and another 31 properties are being processed through the CDBG-DR program. The remaining 15 properties have withdrawn their eligibility from the voluntary acquisition program for multiple reasons.

\section{b. Activities of the LTFRG}

The LTFRG's first key activity was to conduct an assessment of unmet needs. This assessment became the basis for developing a case management partnership with the national Voluntary Organizations Active in Disasters (VOAD). A sub-group convened documented 20 conversations about resilience with affected communities. The findings from these conversations were synthesized into nine categories (BoCo Strong n.d.). ${ }^{11}$ The

Phase 2, and provide direction for Boulder County participation in projects implemented by watershed coalitions. County Commissioners provided unanimous support for the EWP program implementation.

11 "What worked well for my community," "Areas of improvement for my family," "Areas of improvement for my community," "Areas of improvement overall," "What worked well for my family," "What worked well overall," "Recommended actions for my family," "Recommended actions for my community," and "Recommended actions overall." The most popular responses to these prompts are captured in a BoCo Strong handout. 
group found that the concept of community resilience took was an important concept to facilitate conversations with the community.

Based on this finding, a component the LTFRG evolved into BoCo Strong, an independent community collaborative, focused on strengthening social networks and the social infrastructure. BoCo Strong received a $\$ 300,000$ grant through the county's allotment of CDBG-DR Phase 1 funds to improve community resilience through the following four efforts: (1) create and build a local VOAD; (2) establish a resilience network of all local resilience efforts and hold quarterly resilience meetings; (3) conduct resilience assessments; and (4) support community capacity building by developing resilience leadership across the county.

\section{Boulder County Collaborative for CDBG-DR Funds Allocation}

The U.S. Department of Housing and Urban Development's (HUD) CDBG-DR program serves to satisfy a portion of unmet disaster recovery needs in presidentially declared major disaster areas that exist after the award of other Federal agency and private insurance funds. The State of Colorado's Department of Local Affairs is the lead agency for the identification, allocation, and distribution of CDBG-DR funds. Recognizing the unique impact of the 2013 floods, Boulder County communities opted through an intergovernmental agreement to establish the Boulder County Community Development Block Grant-Disaster Recovery Collaborative to process CDBG-DR projects for the community. The Collaborative elected to participate in the CDBG-DR program through a

suballocation process where the Collaborative, instead of the State, would be the authority responsible for identifying unmet needs and prioritizing, distributing, and managing the county's suballocation of the State's CDBG-DR award (State of Colorado 2015). The City of Longmont is the lead agency for the Boulder County Collaborative.

The Collaborative is responsible for meeting HUD requirements for CDBG-DRfunded projects within the county. In response to HUD CDBG-DR program requirements that grantees "identify and implement resilience performance standards that can be applied to each infrastructure project," (Department of Housing and Urban Development 2014, 31968) the Collaborative developed a Resilient Design Performance Standard to assess candidate projects (Boulder County CDBG-DR Collaborative 2016).

The development of the Resilient Design Performance Standard incorporated guidance provided by the State of Colorado's Resiliency Framework and implemented components of the NIST Community Resilience Planning Guide for Buildings and Infrastructure Systems to establish time-to-recovery goals for county building clusters and infrastructure systems (National Institute of Standards and Technology 2015). The Collaborative's standard document establishes a three-step process for setting a resilience performance standard and evaluating proposed CDBG-DR projects. The first step establishes infrastructure and building-cluster-specific time-to-performance criteria for 
each jurisdiction within the county and requires the specification of the appropriate design hazard level (i.e., 100-year flood design standard). These criteria become inputs into project design. The second step scores a proposed project against a set of resilience criteria and indicators, which incorporate the time-to-recovery performance goals established in the previous step. The criteria rely on the State of Colorado Resiliency Framework and indicators were developed using the characteristics of social resilience established through BoCo Strong's resilience assessment with other technical factors and socio-ecological research findings. These criteria become inputs into project design. The third step involves developing a business case for the proposed project, including alternatives, cost and expected return for the community, and a description of the environmental, social, and economic impacts of the project.

This is the first application of resilience design standards to a public granting decision process, to the authors' knowledge. In the coming years, the Collaborative will continue to track the performance of funded projects using the performance criteria established in the standards document. Lessons learned from the application of these criteria and the standards development process could inform the design of future grant program and project performance requirements for the resilient design of infrastructure projects.

\section{Summary of Long-Term Actions and Policy Decisions}

\section{a. Infrastructure actions and decisions}

- Enforced floodplain regulations on an expanded hazard zone: Boulder County made the decision to enforce floodplain regulations per the new (interim) floodplain maps being developed by the Colorado Water Conservation Board, which are expected to bring thousands of additional properties into the floodplain. As a result, the next time property owners in the newly defined floodplain make any substantial changes to their homes, they will have to ensure that the full structure is brought into compliance with floodplain regulations, including elevating the structure to allow for 2 feet of freeboard (i.e. space between the structure and a specific flood level).

- Implemented the Comprehensive Creek Restoration Program: The county partnered with a coalition of residents to form the Comprehensive Creek Planning Initiative in spring 2014, with the intention of planning and proposing creek restoration projects. These plans were approved by the County Commissioners in February 2015, at which point the initiative transitioned to the Creek Recovery and Restoration Program, with the objective of securing funding for and overseeing these projects.

- Established the Collaborative to apply for and allocate CDBG-DR funds: Boulder County communities decided to establish the Boulder County 
Community Development Block Grant-Disaster Recovery Collaborative ("Collaborative") through an intergovernmental agreement. The Collaborative elected to participate in the CDBG-DR program through a suballocation process whereby the Collaborative, instead of the State, would be the authority responsible for identifying unmet needs and prioritizing, distributing, and managing the County's suballocation of the State's CDBG-DR award.

- Developed a Resilient Design Performance Standard for infrastructure and dependent facilities: The Collaborative developed a Resilient Design Performance Standard to assess candidate projects in response to the HUD CDBG-DR requirement that grantees "identify and implement resilience performance standards that can be applied to each infrastructure project" (see (Department of Housing and Urban Development 2014, 31968). The development of this standard incorporated guidance provided by the State of Colorado's Resiliency Framework and implemented components of the NIST Community Resilience Planning Guide for Buildings and Infrastructure Systems to establish time-to-recovery goals for county building clusters and infrastructure systems.

\section{b. Actions and decisions to meeting community needs}

- Participated in FEMA and CDBG-DR acquisition program: The Department of Land Use identified 65 properties in Boulder County for participation in the FEMA HMGP and the HUD CDBG-DR, which provides Federal funds to underwrite a local jurisdiction's property acquisition program. As of early 2017, 19 properties are being processed through the HMGP and 31 properties through the CDBG-DR program.

- Organized resilience dialogues within the community: The LTFRG conducted a survey of community members about unmet needs during the flood recovery process. One finding was that the community was seeking to put in place stronger social infrastructure before the next disaster event. Based on these findings, a coalition of community members and institutions coalesced into a group called BoCo Strong, which focuses on strengthening social networks and social resilience. Two of BoCo Strong's current efforts are establishing a resilience network within the county and developing resilience leadership through capacity-building workshops and exercises. 


\section{Case Study 2: City of Boulder}

\section{A. Pre-Flood Preparedness Planning and Programs}

The City of Boulder has a long-history of flood mitigation planning through the use of engineered drainageways and the employment of land-use planning practices that avoid development within recognized floodplain boundaries. The earliest reports of citizen organizations and municipal officials involved in flood management date to 1910, where the philosophy of avoiding the development of the floodplain to avoid future damage and losses was recognized. Current city officials and utility managers have high regard for the influence of Gilbert White, a prominent Boulder resident, and often refer to him as the "father of floodplain management." In 1966, he advocated for the City of Boulder and Boulder County to consider alternative approaches to floodplain management, such as land-use planning. These approaches were contrary to then-contemporary constructed and engineered protective systems. Statements from community leaders in the 1970s indicate advocacy for non-structural or natural flood management methods, some of which have become components of the modern Boulder stormwater management system (City of Boulder 2004).

As described in the city's most recent Comprehensive Flood and Stormwater Utility Master Plan (further referred to as the "Comprehensive Plan"), the floodplain management policy discussions of the $20^{\text {th }}$ century are still relevant (City of Boulder 2004). The underlying factors and tradeoffs considered by previous Boulder residents continue to be important for policy discussions and decisions facing current city officials and residents.

This chapter details the current approaches that the City of Boulder employs to mitigate or reduce the impacts of floods on city residents and ecological systems. The following discussion focuses on efforts employed by the City of Boulder's government to invest in stormwater management infrastructure, including the design of a comprehensive stormwater management program, broader multi-hazard mitigation planning efforts, and administrative efforts to ensure financial resources are available for emergencies.

\section{Comprehensive Stormwater Management Planning}

Stormwater management is handled by the Stormwater and Flood Management Utility, which is part of the city's Public Works Department. The utility operates as an enterprise that is funded by monthly utility fees levied on all residents and commercial entities within the city limits. The utility is responsible for managing, planning, and 
administering the city's programs and projects relating to flood management, stormwater quality, and stormwater drainage.

The City of Boulder's Comprehensive Flood and Stormwater Utility Master Plan (City of Boulder 2004) describes the policies, plans, and programs under which the city utility provides services to the community. This plan was last updated in 2004, from an earlier version published in 1989. This document provides strategic direction to the stormwater utility in designing and implementing programmatic investments to address stormwater goals. This guiding document contains the policy, regulatory, and infrastructure investment programmatic priorities of the city utility responsible for managing stormwater flooding risk.

The objectives of the City of Boulder's Comprehensive Flood and Stormwater Utility Master Plan are to (1) ensure that the utility can provide services that address flooding hazards, stormwater quality, and stormwater drainage; (2) provide administrative capacity for program integration and implementation; and (3) consider the financial implications in the design and implementation of programs and plans. The remainder of this subsection focuses on policies and programs that the City of Boulder stormwater utility has planned, established, or implemented to mitigate flooding risks.

The following subsections contain highlights from the City of Boulder's Comprehensive Flood and Stormwater Utility Master Plan that are key strategic elements guiding the utility's approach to program design, implementation, and critical infrastructure protection.

\section{a. Notable policies guiding stormwater management strategy}

The City of Boulder stormwater utility incorporates policies established by the City Council through policy statements in the Boulder Revised Code and the long-term development vision articulated in the Boulder Valley Comprehensive Plan. ${ }^{12}$ Notable policy statements providing guidance to the City's stormwater utility in mitigating flood risk include the following:

- Boulder Creek and its tributaries should be established and recognized as unifying urban design elements.

- Protection and restoration of ecological systems and processes, including wetland protection, should be an element of the city's development plans.

12 The Boulder Valley Comprehensive Plan published in 2000 was the last version to inform the City of Boulder Comprehensive Flood and Stormwater Utility Master Plan. Since the publication of the 2004 City of Boulder Comprehensive Flood and Stormwater Utility Master Plan, revisions to the Boulder Valley Comprehensive Plan were published in 2005 and 2010. See Boulder County 2016 a. 
- Flood management plans should consider the functional and aesthetic qualities of waterways, thereby preserving and enhancing them. Non-structural approaches that emphasize a natural appearance should be used on all major drainageways.

- In high hazard flood areas, the city should prevent the redevelopment of significantly flood-damaged properties and prepare plans for the acquisition of flood-damaged and undeveloped lands in these zones. Undeveloped areas in high hazard areas will be maintained in their natural state. Development of trails or other open recreational facilities is a consideration for high hazard areas.

To reflect these policies and guidelines issued by the City of Boulder and Boulder County's Comprehensive Plan (Boulder County 2016a), the City Council adopted the following guiding principles on flood management for the Stormwater and Flood Management Utility (referred to as "the utility" for the remainder of this chapter): (1) preserve floodplains through multiple programs that acquire lands in the high floodhazard zone and integrate multiple city programs into the maintenance of these zones; (2) prepare for floods based upon updated flood mapping and coordination with the Boulder Office of Emergency Management; (3) provide information and incentives for residents to take actions to reduce or transfer flooding risk; (4) prevent adverse impacts and unwise uses in the floodplain through regulation, acquisitions, and planning; and (5) implement flood control measures, including engineered structures and non-structural/ natural measures, that accommodate floods in the region.

\section{b. Floodplain mapping and risk assessment}

The City of Boulder's Comprehensive Flood and Stormwater Utility Master Plan encourages the utility to implement a program to update and maintain floodplain mapping on a 10-year cycle, which requires the utility to implement a project that maps the city's waterways at a rate of at least one waterway per year. The plan's recommendations suggest that the frequency of map revisions that take place with FEMA's Letter of Map Revisions (LOMRs) process or individual studies that only examine limited reaches of a drainageway are insufficient for the city's flood management purposes.

In addition to recommendations on mapping, the plan identifies risk assessments as an important element to interpret floodplain mapping and support resident, utility, and city council decision-making. Risk assessments provide analysis in addition to the maps that considers properties and structures likely to be impacted by flooding, the frequency of expected flooding, the depths and velocities of flood water, the evaluation of life safety threats, and the estimation of expected damages. 


\section{c. Flood management regulatory approaches in the City of Boulder's Comprehensive Flood and Stormwater Utility Master Plan}

Regulatory measures are a key element of the city's effort to mitigate flooding risk. The city adopted the following floodplain regulations before the 2013 floods (City of Boulder 2009):

- New structures within the floodplain require structural design of 2 feet of freeboard above the advisory base flood elevation (i.e., 2 feet of additional space between the structure and the 100-year flood elevation in a given location) and cannot have basements or below grade crawlspaces.

- New structures and additions in the high hazard zone are prohibited (see Figure 5).

- Improvements in the conveyance zone shall not increase the flood elevation (see Figure 5).

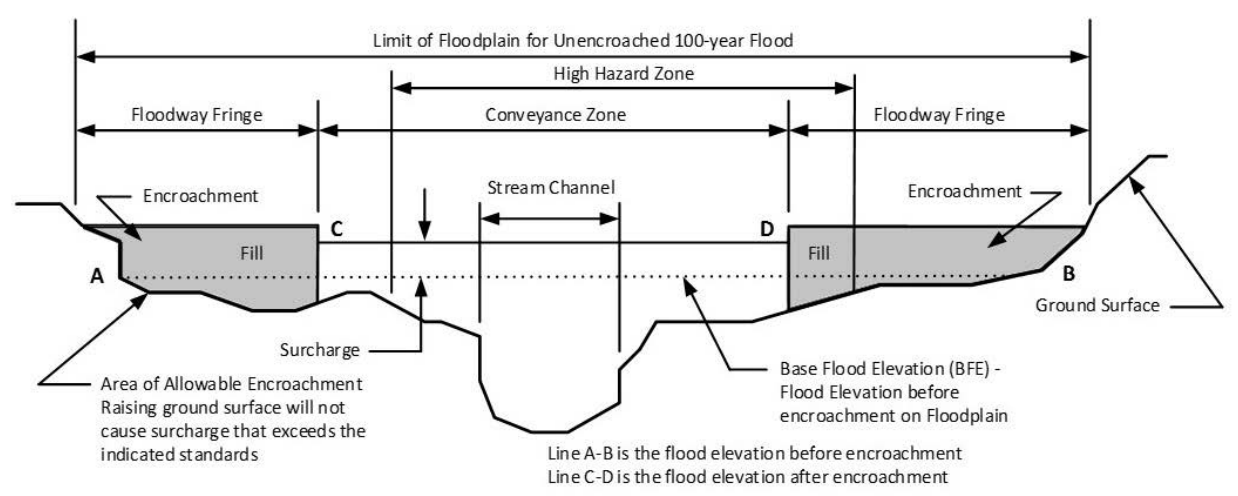

Source: City of Boulder (2014b), 7.

Figure 5. Components of the 100-Year Floodplain

In addition to these regulatory measures, the plan describes several issues on which the utility should conduct research and analysis for future regulatory consideration: addressing floodplain mapping uncertainties, developing 500-year flood protection standards for critical facilities, identifying hazard analysis standards to conduct risk-based evaluation of proposed floodplain development, and establishing consistent stormwater regulations between the City of Boulder and Boulder County for regions that have the potential to be annexed by the city.

\section{d. Property acquisition and flood mitigation}

The 2004 Comprehensive Plan indicates that the combined resources applied to constructed flood mitigation projects and property acquisitions constitute most of the utility funding for flood management. The city's property acquisition program operates by 
acquiring buildings and properties on a prioritized basis and occasionally on an opportunistic basis as properties are listed for sale. As of the 2004 publication of the City of Boulder's Comprehensive Flood and Stormwater Utility Master Plan, the city had acquired 134 of 279 properties within the high hazard zone, and upgraded flood control measures within the acquired floodplain. The city allocates $\$ 500,000$ each year from the stormwater and flood management capital improvement program for property acquisition (City of Boulder 2014b, 9).

Recommended actions for the stormwater utility within the Comprehensive Plan encourage the use of floodplain risk assessments as the basis for setting priorities for mitigation projects and property acquisitions. These risk assessments would be conducted in conjunction with the process recommended for floodplain mapping updates. Information from the assessments would inform the implementation of recommendations to balance the use of constructed flood mitigation projects, property acquisitions to manage and preserve the floodplain, and the evaluation of non-structural alternatives for flood mitigation.

\section{Greenways Program}

In 1984, the City of Boulder adopted the Boulder Creek Corridor Project, which was the predecessor for the subsequent adoption of the city's first master plan for the city's Greenways Program in 1989. The Greenways Program provides the multi-use system that uses engineered and natural systems to meet several goals: riparian, floodplain, and wetland protection and restoration; water quality enhancement; stormwater drainage; transportation corridors; recreation facilities; and cultural resource protection. The combination of the development of the Greenways Program with stormwater management goals creates opportunities for multiple uses of infrastructure to achieve community goals and engage community members with the variety of services provided by stormwater infrastructure systems (City of Boulder 2011). Discussions with officials from the Public Works Department highlighted the program's value in delivering multiple public and ecosystem services, while increasing residents' exposure to infrastructure systems that provide these services.

The Greenways Master Plan (City of Boulder 2011), last updated in 2011, describes these multiple objectives, which span the responsibilities of city government departments. Recognizing the administrative challenges associated with delivering public services for multiple uses, the city government maintains a Greenways Coordinator within the Public Works Department. The Greenways Coordinator acts as an interdepartmental liaison who works closely with an interdepartmental staff (the Greenways Coordination Team) to coordinate and represent the various objectives of the Greenways Program. Maintenance for the system is distributed over the city's Transportation, Open Space and Mountain Parks, and Public Works Departments. The interdepartmental staff also includes non-city public property managers from Boulder Valley School District, the University of Colorado 
at Boulder, and the Boulder County Transportation Department. Funding for the program comes from several sources. The program is funded at a level of $\$ 450,000$ per year, which is provided in equal contributions from the city's transportation fund, the flood control fund, and State lottery funds (administered by the city's Parks and Recreation Department). Supplemental funding from grants or bond sales are identified for stand-alone projects that fall within the greenways capital improvement plan. Minor rehabilitation projects are supported by funds from the Urban Drainage and Flood Control District.

\section{Multi-Hazard Mitigation Planning}

The City of Boulder maintains a Multi-Hazard Mitigation Plan (2012) that serves as a tool for city decision makers to plan and prioritize hazard mitigation activities and the allocation of resources (City of Boulder 2012). This report serves to meet the requirements of FEMA's HMGP, Hazard Mitigation Assistance (HMA) Grant Program, and PreDisaster Mitigation (PDM) Program and meets requirements to reduce community insurance premiums under the NFIP's Community Rating System (CRS). The last update for the plan in 2012 employed the FEMA Disaster Mitigation Act of 2000 (DMA) and CRS planning process. This included an interdepartmental effort, participation from regional and county government agencies, community organizations, and residents. Per the requirements of the DMA and CRS planning process, a multi-hazard risk assessment process was implemented and identified mitigation actions that were applicable for multiple hazards and specific actions for floods, human health, wildfire, and drought hazards.

Flood-related mitigation investments identified in the plan reflect measures described in the city's Comprehensive Flood and Stormwater Utility Master Plan and Greenways Master Plan. Identified flood mitigation actions and progress reported in 2015 include the following:

- Enhancing the city's flood warning system on the city's smaller tributaries by installing cameras or rain gauges. In 2013, the city installed a camera along Bear Canyon Creek and is continuing to evaluate options for cameras along Fourmile Canyon Creek.

- Developing a critical facilities floodplain ordinance. On October 1, 2013, the City Council adopted an enhanced floodplain ordinance that requires higher flood protection standards for critical facilities located within the 500-year floodplain. This ordinance became effective in March 2014 (Brautigam, Fetherston, Rait, et al. 2013a, 2013b; City of Boulder 2016g). (Additional information on this action is provided in the midterm recovery section.)

- Relocating a city fire station outside of the 100-year floodplain. As of 2015, the city is conducting studies to plan for a new fire station outside of the 100 -year 
floodplain. An April 2015 update to the city's Fire Master Plan provides space and cost estimates for the new station.

- An update to the Comprehensive Flood and Stormwater Master Plan is proposed. Funding for a study is scheduled for 2017.

- Implementing floodplain mapping updates, proceeded by development or updates to flood mitigation plans on an ongoing basis. As of 2015, mapping for Boulder Creek, Bear Canyon Creek, Upper Goose and Twomile Canyon Creeks, and Boulder Slough has been updated and adopted. Mapping for Skunk Creek, Bluebell Canyon Creek, and Kings Gulch is taking place. Flood mitigation plan development was accelerated after the 2013 flood, and mitigation studies have been developed for many creeks.

- Acquiring properties in the flood high hazard zone as opportunities become available. As of 2015, the city had acquired 11 properties as part of the property acquisition program. It continues to budget $\$ 500,000$ annually for this program (City of Boulder 2015b).

\section{Financial Preparedness}

Before the 2013 flood, the city had been implementing plans to increase general fund reserves for over a decade. These general fund reserves were to be used in the event of a major disaster. Starting in the late 1990s, the city's general fund reserve was approximately 3 percent of the annual general fund budget. In an effort to ensure that sufficient general fund reserves were available in the event of an emergency, the city increased reserves to 15 percent of the annual general fund budget in 2004 and in 2012 (City of Boulder 2015a).

\section{Summary of Pre-Flood Preparedness Planning and Programs}

\section{a. Infrastructure actions and decisions}

- Raised funds through the Stormwater and Flood Management Utility: The City of Boulder houses a Stormwater and Flood Management Utility in the Public Works Department. The utility is an enterprise that raises funds through fees levied on residents and commercial properties within the city's limits. The utility is responsible for implementing programmatic initiatives to achieve the stormwater-related goals and policies of the city.

- Established flood management policy through a comprehensive utility planning process: The city provides a signal of its flood management and stormwater goals through the development of a comprehensive flood and stormwater utility master plan. Last published in 2004, the Comprehensive Plan describes the city's goals for stormwater management provides guidance to the 
city's stormwater utility on priority initiatives to consider and advises decision makers on regulatory and financial requirements to meet city stormwater management goals.

\section{b. Actions and decisions to meet community needs}

- Established a Greenways Program to delivery multiple public services to residents, including flood management services: The City of Boulder Greenways Program maintains the multi-use pathway system that is coordinated by an inter-departmental team in the city government. The Greenways Master Plan, most recently published in 2011, describes policies implemented by the program, establishes opportunities for maintenance and growth of the system, and identifies funding and maintenance priorities for the program. Objectives of the program include providing stormwater and flood management, riparian and wetland protection, transportation, recreation, and cultural resource protection. The Greenways Program receives funding from several city sources representing the many objectives of the program.

- Maintained a general fund reserve for disaster response and recovery expenditures: The city has maintained a general fund reserve for disaster response and recovery expenditures equal to approximately 15 percent of the general fund budget ahead of the flood. These financial resources provide the city the ability to prioritize response and recovery expenditures without relying upon external grants or determination of FEMA reimbursement applications.

\section{B. Emergency Response Actions and Decisions}

\section{Governance Structure for Emergency Response Actions and Decisions}

In the immediate aftermath of the flooding event, the city organized its leadership into an incident command structure that was coordinated by the Deputy City Manager. This organizational structure worked directly with the Boulder Office of Emergency Management, which provided formal emergency response coordination for the City of Boulder and Boulder County. The city's organizational response structure focused on providing public safety services, with an emphasis on police, fire, emergency medical services, communications, and utilities response. This organizational structure was focused on coordinating efforts across the city government to ensure the deployment of Emergency Response Functions. This "top-down" organizational structure was sustained through the response period and into the early phases of recovery when the city government modified its governance structure. Further discussion on this shift to a recovery-focused governance structure is provided in subsection C.2. 


\section{Infrastructure Impacts and Emergency Maintenance Actions}

\section{a. Stormwater infrastructure}

The City of Boulder relies upon the natural and engineered waterway system of the eight watersheds within its city limits to convey stormwater from the western to the eastern extents of the city, where the tributaries meet at their confluence and join Boulder Creek. The City of Boulder Public Works Department maintains responsibility for the planning, operation, maintenance, and recovery of the city's stormwater infrastructure.

Within the city limits, engineered creek structures were damaged in the storm due to channel or bank erosion, sediment and debris accumulation, and structural damage to drop structures and culverts. Immediately after the event, the city estimated that 100 percent of the 160 miles of pipe comprising the constructed components of the stormwater system would need to be inspected and cleaned. Emergency actions were limited to pumping and sediment removal. Efforts focused on subsequent cleanup, which included debris and sediment removal to restore the system's conveyance capacity and functionality to meet other non-flood stormwater objectives (e.g., water quality, recreation). In total, the repair to damaged waterways and repair or replacement of damaged structures resulted in 27 projects needed to restore the system (Brautigam and Rait 2015).

\section{b. Water infrastructure}

Providing water service in the Boulder region relies upon the natural hydrology, which employs inter-seasonal storage of water in reservoirs and snowpack. The form (e.g., water, snow) and the quantity of precipitation on an annual basis can vary significantly. The City of Boulder's water system maintains reservoirs to supply water from high precipitation years during lower precipitation years. The City of Boulder Public Works Department manages several reservoirs and watersheds feeding the city's water supply. These reservoirs and watersheds include the Barker Reservoir, the Lakewood Reservoir, and the Silver Lake Reservoir in the foothills that supply the Betasso Water Treatment Facility and the Colorado Big Thompson/Boulder Feeder Canal and Boulder Reservoir that supply the Boulder Reservoir Water Treatment Facility. The Betasso Water Treatment Facility is located in the foothills and feeds the gravity flow water distribution system. The Betasso Facility and its associated reservoirs supplies 80 percent of the city's drinking water. The Boulder Reservoir Water Treatment Facility is located in the northeastern extent of the City. Water is subsequently pumped to the city's water supply intake. This facility supplies the remaining 20 percent of the city's drinking water supply and provides additional supply capacity to meet seasonal peak demand.

During the 2013 floods, several water treatment and distribution system components and facilities were damaged, affected, or taken offline due to direct flooding or indirect effects due to infrastructure interdependence. Despite these issues, the city was able to 
maintain uninterrupted service for water availability, pressure, and quality. No downtime or degradation of service was experienced during or after the event due to redundancy within the system and actions taken by Public Works Department officials. Although service was uninterrupted during the flood, the degradation and damage to the system highlighted vulnerabilities in the water supply, treatment, and distribution systems. These vulnerabilities are discussed below.

\section{1) Betasso Water Treatment Facility and associated infrastructure}

Public Works Department officials worked diligently to ensure that the Betasso facility remained operational. Due to the Betasso facility's location in the foothills, the electrical grid is vulnerable to outages, and the facility experienced an electricity outage during the storm event. Backup power generators were available; however, insufficient generator fuel was stored at the facility for the full duration of the event. In addition, treatment chemicals to operate the facility for the length of the flood event were insufficient. As a result of pipeline damage due to erosion and unstable slopes in Boulder Canyon, only one water pipeline - the Sunshine Pipeline - was in service for the duration of the event.

Public Works officials had difficulty accessing the site due to poor road conditions and road washouts. Officials coordinated efforts to deploy large equipment to provide temporary transportation access and worked with Colorado Department of Transportation to deliver sufficient fuel and water treatment chemicals to maintain full operations of the facility throughout the flood.

\section{2) Boulder Reservoir Water Treatment Facility}

The Boulder Reservoir Water Treatment Facility was inoperable immediately after the flood. The primary inlets into the facility at the time of the flood were uncovered trenches. As a result of this unprotected construction, flood waters increased sediment and debris loads in the reservoir. The flood event was estimated to impose a sediment load on the system that was twice the annual average load, resulting in high turbidity. Sediment loads in the Boulder Reservoir remained elevated above normal levels throughout 2014. They returned to normal levels at the end of 2014 (Arthur et al. 2015, Agenda Item, page 2)

\section{c. Wastewater infrastructure}

The City of Boulder's wastewater system is managed by the Utilities Division of the Public Works Department. Although the wastewater infrastructure suffered significant damage and degraded capacity in the event, the wastewater treatment plant remained fully operational throughout the event, despite being overcapacity through the duration of the event. 
The wastewater collection system experienced operational issues originating from significant groundwater infiltration into the clay pipes of the collection system and from surface flow into the system through manhole covers, basements, and other sources. A primary sanitary sewer interceptor line, a $102 \mathrm{~cm}$. (40 in.) diameter pipe connected to the waste water treatment plant, experienced severe erosion and scour around the pipe. Due to Boulder Creek flooding and high flow rates, the severe erosion and scour resulted in a nearfailure event for this primary interceptor line (Boulder County 2015, 2). Despite this near failure, the pipe remained in service and continued to convey sewage to the wastewater treatment plant throughout the flood event. Emergency repairs stabilized the $102 \mathrm{~cm}$. (40 in.) interceptor line. Subsequent recovery stage repairs to the interceptor line were designed to reroute the line away from locations that would be prone to significant erosion in future flooding events.

Components of the wastewater treatment plant were damaged during the flooding and storm, resulting in damage to the facility headworks and an anaerobic digester cover. No breaches in the facility flood berm were experienced during the event, which protected the site and facility from potential damage (Brautigam and Fetherston 2013a).

Groundwater infiltration into the sewer system, combined with the significant loading

on a hydraulically limited sanitary sewer system, resulted in significant sewage backup throughout the city's system. Sewage backup was the primary wastewater-related impact of the flood on the city's residents. Backup into residences and commercial buildings occurred throughout the city, and significant backup was observed in the area around South Boulder Creek and Bear Canyon Creek. The City of Boulder estimates that sanitary sewer backups resulted in approximately $\$ 26.8$ million in damages (City of Boulder 2014c).

\section{Open Space and Natural Resource Impacts}

The City of Boulder Open Space and Mountain Parks Department (OSMP) Department manages over 45,000 acres of preserved open space, which contains and requires the maintenance of approximately 150 miles of greenways and trails and the preservation and protection of riparian areas that serve as critical wildlife habitat. The Open Space and Mountain Parks are consistently cited as a major recreation, cultural, and natural resource preserved and maintained by local government for the enjoyment of its citizens.

The 2013 floods resulted in significant damage to OSMP facilities, trails, and preserved habitats. All of the OSMP trails were damaged in the floods, with 64 percent of the trails experiencing significant to severe damage. Due to the significant damage throughout the trail system, as a public safety precaution, OSMP management closed the system after the flood. 
OSMP facilities suffered from damage to fences and bridges. Ditches had to be repaired. The City of Boulder OSMP estimates that the cost of repairing trails, facilities, and ecological restoration projects will total $\$ 8$ million.

\section{Resident Needs and Impacts}

\section{a. Community outreach, debris management}

Immediate response activities were coordinated at the EOC; however, the Planning, Housing, and Sustainability Department was involved in some response functions, such as community outreach, debris management, and damage assessments. The department compiled a Frequently Asked Questions (FAQ) information sheet about flood recovery for community members and updated it hourly for the first few days as new questions arose. Department staff coordinated debris management activities and set up community drop-off locations for debris. The drop-off locations quickly became overwhelmed, so the city transitioned to a curbside pickup program.

\section{b. Residential impacts}

The City of Boulder issued a survey and published the results of an analysis in December 2014 of the flood's impact on private property and residents. The city's report was based upon a survey distributed to 8,500 residents who were likely to have been impacted by the flooding. Survey results were extrapolated based upon FEMA Individual Assistance Program data to ascertain damage estimates for city residents and private property. Private residential damage due to the flood event was caused by several factors: drainageway flooding into private property, groundwater infiltration into homes and basements, sanitary sewers backing up into private residences, and so forth.

The city's analysis estimated a total of $\$ 194.9$ million in damage. This damage figure includes four outlier reports of damage: \$10 million for the South Boulder Creek basin, \$6 million for the Wonderland Creek basin, $\$ 1.5$ million for the Twomile Canyon Creek basin (outside of the 100-year floodplain), and $\$ 1$ million for the Boulder Creek basin (outside of the 100-year floodplain). The remaining damages, $\$ 176$ million, can be attributed to damage from the sources indicated in Table 1. Over 70 percent of the damage was experienced within the Boulder Creek (\$41 million), Twomile Canyon Creek (\$39 million), South Boulder Creek (\$28 million), and Bear Canyon Creek basins (\$18 million). 
Table 1. Total 2013 Flood Event Out-of-Pocket Damage Costs (as Reported by the City of Boulder)

\begin{tabular}{lcc}
\hline & Total & Percentage of Total \\
\hline Major drainageway flooding & $\$ 31,267,343$ & $18 \%$ \\
Groundwater infiltration & $\$ 40,33,002$ & $23 \%$ \\
Flooding from local drainage & $\$ 44,957,530$ & $25 \%$ \\
Flood drain damage & $\$ 15,740,096$ & $9 \%$ \\
Sanitary sewer backup & $\$ 26,815,555$ & $15 \%$ \\
Other & $\$ 17,255,438$ & $10 \%$ \\
Total estimated damages & $\$ \mathbf{1 7 6 , 3 6 8 , 9 6 4}$ & $\mathbf{1 0 0} \%$ \\
\hline
\end{tabular}

Source: City of Boulder (2014c, 3).

\section{Summary of Emergency Response Actions and Decisions}

\section{a. Infrastructure actions and decisions}

- Maintained water service from the Betasso Water Treatment Facility and Sunshine Pipeline: The City of Boulder water treatment and distribution infrastructure was degraded and damaged in the 2013 floods. Redundancy in the system and efforts taken by city officials to deliver fuel and treatment chemicals to the Betasso Water Treatment Facility ensured that the system was online throughout the event. Water service was not interrupted during the event. Impacts to the system, particularly the temporary loss of the Boulder Reservoir Water Treatment Facility, highlighted system and component vulnerabilities.

- Repaired primary wastewater interceptor line: The structural integrity of a primary wastewater interceptor pipeline located near the city's wastewater treatment plant was in jeopardy during the 2013 flood. This interceptor line experienced major erosion from floodwaters, requiring emergency repairs to reinforce the structural support for the pipe and prevent breaches or untreated sewage discharge.

\section{b. Actions and decisions to meet community needs}

- Established incident command structure in city government: The city organized its emergency response activities through an incident command structure that was led by the Deputy City Manager. Through this organizational structure, the city coordinated with the Boulder Office of Emergency Management, which maintains the county's EOC. 
- Distributed information to residents through frequently asked questions list: The city responded to questions from residents by creating and distributing a list of FAQs online. This listing was updated frequently, in fact, hourly, as the immediate flood response was taking place.

- Coordinated debris collection: Residents required debris clean-up and collection services immediately after the flood. The city implemented flexible collection services and drop-off locations to meet changing needs throughout the city.

- Closed Open Space and Mountain Parks facilities: Due to expectations of significant damage within the trail system maintained by OSMP and to ensure public safety of users of OSMP trails and facilities, the city closed all OSMP trails and facilities immediately after the flood.

\section{Midterm Recovery Actions and Decisions}

\section{Context and Considerations for Midterm Recovery Efforts}

Concurrent to the activation and activities of the EOC, the City of Boulder government needed to address these needs and concerns of its residents that were not being met by the EOC. While supporting emergency response needs, the staff within the City Manager's Office focused on establishing a new governance structure for coordinating midterm and long-term recovery activities within the city government. The initial flood recovery structure did not meet longer-term recovery and rebuilding needs and was not well-coordinated with the conventional organization and roles of city government departments. As a result, the city flood recovery leadership designed and implemented several organizational and governance structures throughout the recovery phase of the flood event.

The 2013 flood revealed some gaps in preparedness for responding to and recovering from an event of this size but also highlighted the recovery team's ability to identify and address the midterm recovery requirements of the community under numerous constraints. The initial response period provided lessons for the Flood Recovery Team, and these lessons have since been integrated into the new structure and into response and recovery plans for subsequent events. 


\section{Recovery Governance Structure and Establishment and Organization of the City Flood Recovery Structure}

\section{a. Flood recovery structure}

\section{1) First iteration}

On September 19, 2013, the Deputy City Manager led the effort to construct an initial organization for recovery. The staff at the EOC had proposed using the Incident Management System. Using this proposal, the Deputy City Manager created an initial command structure on September 26. This command structure included positions to oversee communications, operations and infrastructure, and community services. The Deputy City Manager served as the Flood Recovery Manager in this structure. The team met twice daily.

This first structure fell outside normal city government departmental roles. It imposed a top-down command and reporting structure, which generated several communicationand coordinated-related issues across city government. This structure relied upon the Incident Management Structure, which included only those departments involved in response activities. City officials quickly found this structure to be incomplete as it did not represent the full set of capabilities and skills that all departments collectively could bring to the recovery effort. As a result, the recovery structure evolved several times after September 2013.

\section{2) Second and third iterations}

In November and December of 2013, once infrastructure and response operations had stabilized, the city government reexamined the recovery process. This examination involved reaching out to county and State counterparts to see how they were organized and consulting the National Disaster Recovery Framework (Federal Emergency Management Agency 2016c). A second iteration of the flood recovery structure was drafted in this time period. This structure brought in a Flood Recovery Manager, who was provided interdepartmental coordination roles and responsibilities, along with a community services and financial roles. The city advertised a new position, "Special Assistant to the City Manager/Finance." The position description included interacting with FEMA and coordinating finances but was written broadly enough so that the employee in this position could assume other flood recovery duties, as needed. While the department was waiting to fill this position, the Deputy City Manager resigned, which accelerated discussions about the institutional structure of flood recovery.

After the Deputy City Manager's departure, the recovery structure underwent a third iteration, which was adopted in April 2014 and remains the current structure in place (see Figure 6). This third iteration included two addition coordinator positions, in addition to 
the previous finance coordinator, dedicated to community services and infrastructure and operations, respectively. The City Manager also named the Executive Director of Public Works as the Flood Recovery Manager. The staff finalized the flood recovery structure by documenting roles and responsibilities and aligning those around the City Council's recovery objectives (Brautigam and Fetherston 2013b).

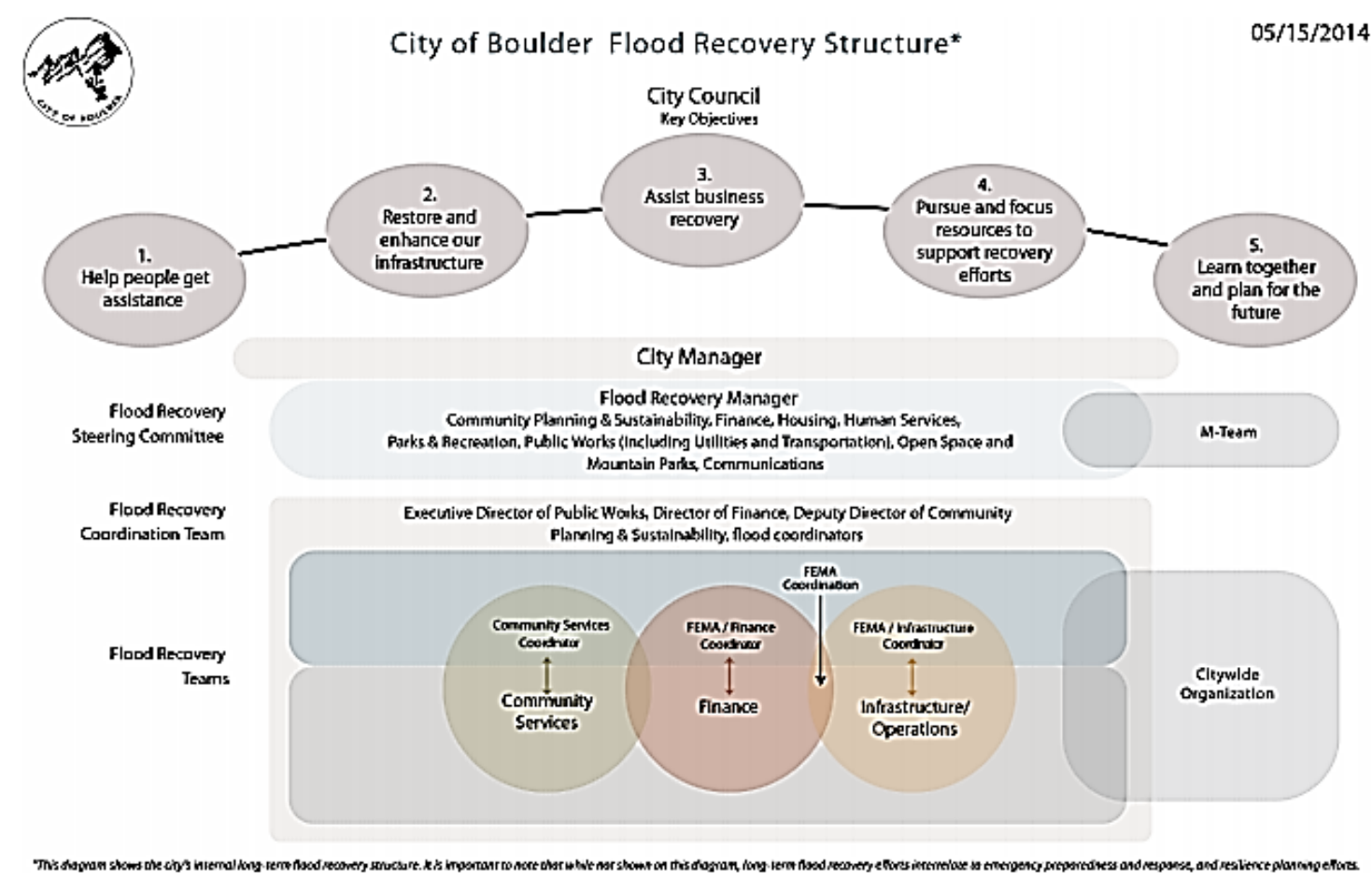

Source: City of Boulder (2015a, 6).

Figure 6. City of Boulder Flood Recovery Structure (May 15, 2014)

In May 2014, with the new structure in place-which included the flood recovery steering committee, Flood Recovery Manager, and flood recovery coordination teamscity government departments were able to drill down into their specific roles and responsibilities relating to community services, infrastructure/operations, and finance. The community services coordinator started organizing around the long-term needs of the community and working with the county long-term flood recovery group and other county government counterparts. The coordinator was responsible for helping individuals and businesses, capturing lessons learned, and planning for future incidents.

\section{b. Disaster transition functions}

The Flood Recovery Team is exploring a disaster transition center for long-term recovery and expressed a need for disaster transition functions, similar to ESFs and Recovery Support Functions (RSFs). Proposed disaster transition functions would include 
activities such as debris management and damage assessments. These functions would aim to ensure that cross-departmental training is put in place such that staff from several departments are trained before the recovery phase of an event to support high-priority activities that may fall outside of their normal departmental roles and responsibilities. The city is currently formalizing and documenting the disaster transition support function proposals. These proposals would be integrated with published FEMA recovery support functions into a joint recovery framework to be implemented across the city and the county.

\section{c. Testing the recovery structure}

As of 2016, the Flood Recovery Team is exploring approaches to ensure recovery lessons learned are maintained within the government long after the flood event. The city government, to ensure that it is ready to respond to emergencies, holds monthly cross-

agency coordination meetings and full-scale disaster exercises every year in May. The city government, through the Flood Recovery Team, wishes to complete the same type of exercise for recovery-phase responsibilities.

In March 2016, the city had a test run for the new structure when a snowstorm led to large-scale damage to trees around the city. Staff from several departments were trained to use a new cloud-based software system that enabled uniform, consistent damage data collection regardless of which department was conducting the assessment. The city was able to mobilize a team of 30 staff members within 5 hours to assess damage from and to trees. Data collected during this assessment provided enough information to make a decision about whether to provide a city-wide cleanup option. City officials responded favorably to the efficacy of this new software and process. The city is working to continue this aspect of pre-event recovery planning and training.

\section{Midterm Resident Needs and Public Services}

\section{a. Disaster assistance centers and public meetings}

The Flood Recovery Team, in coordination with the county government, established two joint DACs in Boulder and Longmont. The Boulder DAC opened on September 19, 2013. By September 25, 2013, it had served 2,773 individuals and 1,194 households, of which 882 individuals and 435 households were residents of Boulder (Brautigam and Fetherston 2013b).

These DACs were staffed by the city government, the county government, the Red Cross, the Salvation Army, the U.S. Small Business Administration, FEMA, the Colorado Department of Local Affairs, and other governmental and non-profit entities. At these centers, residents received food and clothing, information about housing needs and shelter, and additional emergency and long-term recovery assistance (City of Boulder 2013a). 
The Flood Recovery Team also led the cross-departmental community outreach effort within Boulder, which included eight flood recovery open houses. At these meetings, city representatives set up stations with maps of initial high water marks and, to support recovery planning, asked residents to annotate the map to show places that the water level had reached in their area in an effort to collect information about residential impacts. These open houses also served as an opportunity for residents to ask city officials questions about recovery activities and planning. In total approximately 750 residents attended these open houses (Brautigam and Fetherston 2013a).

\section{b. Damage assessments}

The Flood Recovery Team had concerns shortly after the flood about residents who were rebuilding without permits before damage was properly assessed. The city waived permit fees and put additional efforts into rapid damage assessments to avoid rebuilding illegally without permits. The damage assessments were completed in coordination with the Public Works Department and involved teams of building inspectors and permit reviewers. For private properties, the city mobilized the Colorado chapter of the International Code Council, which provided plan reviewers and building officials from neighboring jurisdictions. With this added capacity, a team of 20 individuals was able to conduct a rapid, windshield assessment of the whole city $(22,000$ residences and commercial properties) on September 23 and 24, 2013. This assessment was helpful for capturing the areas of significant damage but was not useful for capturing the impact at a smaller scale, such as identifying individual homes that were unfit for habitation. The rapid assessment was focused on exterior damage only. Officials did not enter homes-except for those with visible interior damage - so they were unable to assess the scale of interior damage. The rapid assessment identified 58 structures as damaged and 12 structures as dangerous (City of Boulder 2015a).

The team also visited all 165 individually landmarked buildings under the historic preservation program (which falls within the Planning, Housing, and Sustainability Department) and did a door-to-door assessment.

After the completion of the assessments, the department staff realized that the assessment process was insufficient for FEMA assistance application requirements, particularly the applications for temporary housing assistance. As a result of this incomplete damage assessment data collection effort, the department relied on data collected by individual residents and FEMA data to fully characterize residential impacts.

\section{c. Emergency ordinance for regulatory waivers}

On October 1, 2013, the Flood Recovery Team advised the City Council to consider passing an ordinance that allowed temporary fee waivers for flood recovery permits, suspensions and modifications to contractor licensing requirements, allowances for 
dumpsters and temporary storage units to be put in the public right-of-way, modifications to camping requirements and establishment of campgrounds, modifications to working hour requirements (so contractors could work earlier and later), and allowances for nonresidential use of mobile homes. These proposed ordinance modifications were first read on October 1, 2013 and adopted on October 15, 2013 (Brautigam, Fetherston, Carr, et al. 2013; Brautigam, Fetherston, Rait, et al. 2013b). Also during these October 2013 City Council meetings, the City Manager instructed city staff to not enforce the city's occupancy limits through January 2014. The modifications to camping requirements, the allowances for dumpsters and storage units in the public right-of-way, modifications to working hours, and the non-residential use of mobile homes were written so as to be effective until April 15, 2014. Modifications to the contractor licensing requirements and waivers for flood-related fees were written to be effective until December 15 and 31, 2013, respectively. On February 18, 2014, the City Council approved a temporary extension of the flood-related fee waivers through March 1, 2015 (Brautigam, Fetherston, Carr, et al. 2014). On March 17, 2015, the City Council approved another year-long extension of fee waivers through March 1, 2016 (Brautigam, Rait, Richstone, et al. 2015). These particular policy changes were prioritized based on the input the department was receiving from community members and departmental staff recommendations. The fee waivers were allowed to expire in March 2016.

Flexibility in enforcing regulatory requirements after a major disaster was a key policy instrument that city officials recognized would be needed in future events. As part of its transition to long-term planning efforts, the Flood Recovery Team is investigating whether authority to grant waivers during emergency situations can be extended to the City Manager without having to convene the full City Council in the immediate period after an event. These efforts aim to increase the speed with which city officials can respond to requests from residents and businesses.

\section{Ordinance for Mandatory Flood Protection for Critical Facilities and Lodging}

As described in the city's Multi-Hazard Mitigation Plan, published in 2012, the city committed to develop a critical facilities floodplain ordinance. (Further information about the Multi-Hazard Mitigation Plan is included in subsection A.3.) Initial proposals, planning, and community outreach for this ordinance began in August 2010, and City Council began considering the ordinance in August 2013. On October 1, 2013, the City Council adopted an ordinance on lodging and critical facilities in the Multi-Hazard Mitigation Plan (City of Boulder 2016g). This ordinance responded to concerns related to vulnerable populations and broader public safety and set two key flood-related facility requirements:

- Critical facilities in the 500-year floodplain that serve at-risk populations or provide essential community services must be flood proofed or elevated, or 
measures must be taken to contain hazardous materials if such materials are stored on the site.

- Critical facilities that serve at-risk populations, provide essential community services, or store hazardous materials and all lodging facilities in the 100-year and 500-year floodplain must develop emergency plans (i.e., evacuation plans, shelter-in-place plans) (Brautigam, Fetherston, Rait, et al. 2013a, 2013b; City of Boulder 2016g).

\section{Financial Resources Available to the City Government}

As discussed in the pre-event preparedness section, the city government maintains general fund reserves as a budgetary buffer for unexpected major expenses or disasters. The availability of reserve funds allowed the city to immediately fund the response and recovery restoration actions that were determined by the city to have highest priority. No modifications to the annual budget were required by the City Council to address disaster recovery efforts, allowing the City Manager to implement emergency response and recovery actions where statutory authority allowed. As a result of this financial prudence, governmental functions and priorities were able to continue unaffected by the financial impact of the flood. After the 2013 floods, the City Council established a budget to restore the reserve to 14 percent of the total budget by 2015 and 16 percent by 2016 and onward (City of Boulder 2015a).

\section{Summary of Midterm Recovery Actions and Decisions}

\section{a. Infrastructure actions and decisions}

- Conducted rapid damage assessments: In the days following the flood, the Flood Recovery Team rapidly assembled teams of municipal government staff to survey damage. The team performed windshield assessments, which provided information on the level of damage experienced but insufficient information to assess damage at the level of individual pieces of property. This assessment found that 58 structures were damaged. Twelve structures were tagged as dangerous. This information was later supplemented by FEMA data on residential damage.

- Passed an ordinance requiring critical or lodging facilities to undertake flood mitigation measures: In October 2013, the City Council passed an ordinance that required critical facilities and lodging facilities that serve at-risk populations, provide essential community services, or store hazardous materials and are within the 500-year floodplain to implement flood mitigation measures when improving or modifying their properties. The ordinance also required the 
same class of facilities and all lodging facilities in the 100-year and 500-year floodplain to develop emergency plans.

- Passed an ordinance to facilitate recovery activities: In October 2013, the Flood Recovery Team advised City Council to pass an emergency ordinance that would temporarily modify contractor licensing requirements, allow for dumpsters and storage units to be placed in the public right-of-way, and extend working hours. This emergency ordinance was passed to expedite the removal of debris and the rebuilding of infrastructure and homes.

\section{b. Actions and decisions to meet community needs}

- Implemented Flood Recovery Team structure to integrate with city government departmental organization: The city government did not have an existing structure for coordinating recovery activities before the 2013 flood event. The city revised its interdepartmental flood recovery structure in spring 2014 to include coordinators for finance, community services, and infrastructure and operations. The Executive Director of Public Works was named the Flood Recovery Manager in the new structure and oversaw the three departmental coordinators. The resulting Flood Recovery Team found the new structure to be more conducive to cross-departmental collaboration and communication.

- Held community outreach meetings to engage residents and receive input on extent of damage and water levels: The Flood Recovery Team, in coordination with several city departments, organized public flood recovery meetings for residents to ask questions about the flood response and recovery. Residents were invited to annotate maps of water levels and share information about flood impacts.

- Established two Disaster Assistances Centers. The City of Boulder and Boulder County jointly established two DACs to provide residents to access resources, seek advice, and complete relevant reimbursement and grant application materials. These centers were staffed by the city and county government officials, the local chapter of the American Red Cross, the Salvation Army, the U.S. Small Business Administration, FEMA, the Colorado Department of Local Affairs, and other local charitable organizations.

- Passed an ordinance waving permit fees, modified campground requirements, and allowed non-residential use of mobile homes: In October 2013, the Flood Recovery Team advised the City Council to pass an emergency ordinance that would temporarily waive permitting fees, modify campground requirements, and allow non-residential use of mobile homes. The ordinance was passed and removed financial disincentives for engaging in the building 
permitting process, assisting displaced residents, and providing alternative locations for businesses with damaged storefronts.

\section{Long-Term Recovery Actions and Decisions}

\section{Context and Considerations for Long-Term Recovery Efforts}

Through the long-term recovery phase, the City of Boulder's governance structure continued to rely upon the Flood Recovery Team established in the initial 6 months after the event. Efforts and considerations of city officials shifted from immediate recovery needs toward strategic programming and infrastructure investment programs to meet challenges posed by future floods. Considerations focused on balancing the needs for accelerated implementation of infrastructure investment plans with the associated increase in utility rates that would be necessary for cost recovery.

\section{Long-Term Infrastructure Recovery}

On August 11,2015, the city manager, representatives from various city departments, and members of the Flood Recovery Team presented a draft version of the 2016-2021 Capital Improvement Program (CIP) at a City Council study session. This budget document was then submitted at the end of August to the Council by the City Manager as part of the 2016 Recommended Budget (Brautigam, Eichem, et al. 2015). In October 2015, City Council approved the CIP funds - as part of the 2016 City Budget - for a 6-year (20162021) program, totaling $\$ 392.7$ million for 157 projects that will improve the physical infrastructure of the city. The approved CIP funding for 2016 was $\$ 74.5$ million, allocated to 109 projects (City of Boulder 2016e).

Another capital improvement initiative, the Capital Improvement Bond Projects, was funded by a bond program voted for in a November 2011 election by a 3:1 margin. Although this bond program was created before the 2013 floods, its impact on the recovery process was important for achieving long-term recovery goals. This ballot item granted the city government the authority to leverage existing revenues - thus not leading to additional taxes - for the creation of a $\$ 49$-million bond package that could be used for critical infrastructure improvement projects. A committee of 16 community members selected the projects funded under this initiative from a list of potential projects totaling $\$ 700$ million. The bond program was designed so all projects would be implemented by March 2015 . As of summer 2016, all but 5 of the 86 projects have been completed (City of Boulder 2016d, 2016i).

The City Council also approved utility rate increases during the 2015 budget process to cover water, wastewater, stormwater, and flood management services. These rate changes were effective January 1, 2015. The revenue goes into three separate funds for 
water (domestic and irrigation), wastewater (sanitary sewer), and stormwater and flood management (City of Boulder 20161).

\section{a. Water}

As part of the 2015 utility rate changes, rates for domestic and irrigation water services were increased by 5 percent. These funds will be used to upgrade part of the water treatment and distribution infrastructure.

As of spring 2016, officials from the Public Works Department continued efforts to seek approval for a project that would build a pipeline to replace the open canal that conveys water to the Boulder Reservoir Water Treatment Plant (the city's secondary water treatment plant). The pipeline would be funded through the city's CIP. The open canal was filled with debris and high sediment loads during the flood, which prevented the treatment plant from remaining operational during the event. This infrastructure upgrade proposal has been presented to the City Council.

\section{b. Wastewater}

As part of the 2015 utility rate changes, the City Council approved a 30 percent increase in wastewater rates, to fund an acceleration of the replacement of clay pipes. These replacements were originally scheduled to be completed over a 100-year trajectory, but the increase in utility rates allowed the Public Works Department to shorten this timeline to closer to 20 years. This funding also allows the department to address internal corrosion issues on the main concrete interceptor. Department officials initially proposed a more modest increase in utility rates, but the City Council decided to accelerate the sewer pipe replacement to a 20 -year time frame.

\section{c. Stormwater and flood management}

The City Council also approved a utility rate increase for stormwater and flood management in the 2015 increase. In absolute terms, this increase in fees was smaller than the wastewater fund, but represented a relative increase 75 percent increase in stormwater utility rates. This fund generates approximately $\$ 12$ million per year. However, some of the flood mitigation projects proposed under this fund will cost $\$ 20$ million or more. Despite the increase in funding, there remains a 100-plus year trajectory to upgrade all city drainageways to 100-year flood design standards at the current pace of work.

The city is about a third of the way through a multi-decadal infrastructure improvement plan to upgrade unimproved or under designed (less than 10-year flood design) drainageways to engineered systems that meet 100-year flood design standards. One obstacle to these improvements are houses and structures that are present in high hazard drainage areas, such as those within the Gregory Creek drainageway. The city cannot implement the 100-year flood design standard in some drainageways without 
acquiring these properties. While the city maintains the property acquisition program for buildings in the high hazard zone, this is a voluntary program and eligible homeowners must opt-in for an acquisition to successfully occur. The city enforces a policy to complete flood mitigation work in areas where it has been able to implement engineering designs to 100 -year flood standards. However, for locations such as Gregory Creek, the Public Works Department is considering building to less stringent standards (i.e., 10-year design standards).

\section{d. Public engagement and support}

City officials recognize that a window existed after the flood during which public interest in and support for capital improvement projects was high. However, many of the projects are long-term efforts, including the flood mitigation projects for major drainageways. Public sentiment for long-term flood mitigation projects varies. Some favor accelerating infrastructure upgrades, while others question the value of public investment in flood mitigation due to differing experiences during the 2013 flood. The city engaged Kathleen Tierney, a professor at the University of Colorado Boulder and Director of the Natural Hazards Center, about windows of opportunity and stages of public engagement after a disaster event. City officials found this information to be helpful in ensuring that their outreach strategies engage and inform residents of the risks and tradeoffs associated with mitigation investment decisions.

\section{Administration of Long-Term Recovery}

\section{a. Finance}

The primary objective of the Finance Department after the flood was to ensure that all expenses incurred by the city in response and recovery activities would be appropriately bid, contracted, tracked, and eligible for FEMA public assistance reimbursement. Immediately after the 2013 flood, the Director of the Finance Department created a charge code for departments to charge their work on flood response and recovery activities. Finance Department staff developed a manual for the city departments on reporting requirements and what the city government should expect from FEMA during the reimbursement process. To enforce purchasing standards across departments, the Finance Director and the Flood Recovery Coordinator for Finance devised a common purchasing system that met FEMA public assistance reimbursement eligibility criteria and required that all departments use the system for flood recovery purchasing.

The city hired consultants to support the preparation of FEMA public assistance reimbursement requests. A representative from the Finance Department and the Flood Recovery Coordinator for Finance served as the primary contacts with FEMA and State representatives. Despite these efforts to impose a uniform set of requirements that met 
FEMA standards, the Finance Department staff received conflicting guidance from FEMA officials and from the consultants on which purchasing policies were strict enough for FEMA standards for Public Assistance reimbursement. As of September 2015, the city has received \$5.6 million in FEMA and state-equivalent public assistance reimbursements out of a total expected reimbursement of approximately $\$ 17$ million (Brautigam and Rait 2015; City of Boulder 2015a).

\section{b. Floodplain mapping}

After the event, city officials conducted surveys and collected data to map the highwater mark experienced across the city's drainageways. These data closely matched floodplain extents represented in the 100-year floodplain map. These combined 2013 flood extent maps and 100-year floodplain extents provided a mechanism to facilitate community meetings to improve community understanding of flooding risks and receive community feedback on flood mitigation needs (City of Boulder 2015a).

As a part of the city's broader flood preparedness initiatives, which began before the 2013 floods, the city's stormwater utility maintained emphasis on continuing floodplain mapping efforts (City of Boulder 2014b). The following subsections describe the status of major floodplain mapping projects that have taken place since the 2013 floods.

\section{1) Boulder Creek}

The city began a study of the portion of Boulder Creek between $61^{\text {st }}$ Street to Boulder Canyon before the 2013 floods and produced revised floodplain maps to replace both the FEMA Flood Insurance Rate Map (FIRM) and the city's floodplain map in September 2013. The revised mapping relied on topographic data and updated floodway and high hazard zone boundaries. This study was submitted to FEMA in September 2013 for the Physical Map Revision (PMR) process, which was delayed by the flood event. On July 23, 2015, FEMA released the preliminary FIRMs, which are expected to be effective in the summer of 2017 (City of Boulder 2016b).

\section{2) Boulder Slough}

The city updated the hydraulic models and flood hazard mapping for a portion of Boulder Slough (30 ${ }^{\text {th }}$ Street to $16^{\text {th }}$ Street). The city used 2013 Lidar-based topographic data for this study. The floodplain maps resulting from this study were displayed for public review on July 9, 2014, and were presented to the Water Resources Advisory Board (WRAB) — which recommended adopting this floodplain map — on July 21, 2014. The

updated map was approved by the City Council on February 3, 2015 (City of Boulder 
2016c). The city submitted its floodplain mapping update for Boulder Slough to the Urban Drainage and Flood Control District (UDFCD) ${ }^{13}$ in February 2015.

\section{3) Bear Canyon Creek}

The city also updated the floodplain mapping for Bear Canyon Creek. The floodplain maps were made available for public review on July 1, 2014, and were presented to the WRAB on July 21, 2014. The City Council approved the floodplain mapping on November 18, 2014. The city submitted a LOMR to FEMA for Lower Bear Canyon Creek in August 2014 (City of Boulder 2016a).

\section{4) Skunk Creek, Bluebell Canyon Creek, and King's Gulch}

In late 2013, the city started the process to update floodplain mapping for Skunk Creek to incorporate observed flooding from the September flood event. The WRAB recommended that the updated mapping receive an additional round of peer review. This round of peer review was completed in January 2015 and resulted in recommendations to investigate and incorporate spill flows from Bluebell Canyon Creek and Skunk Creek. An open house for public review and a WRAB meeting has been scheduled for September 2016 (City of Boulder 2016j).

\section{5) Twomile Canyon Creek and Upper Goose Creek}

Revised floodplain mapping for Twomile Canyon Creek and Upper Goose Creek was presented to the WRAB on March 16, 2015, and approved by the City Council on July 28, 2015. These revised mappings have been sent to and accepted by FEMA. The revised mapping will go into effect on August 18, 2016 (City of Boulder 2016k).

\section{c. Annexations}

One hundred sixty properties in unincorporated Boulder County near the Boulder City limits were not connected to the city sewer system and had private wells that were contaminated and septic systems that failed during the flood because of high groundwater levels. As early as September 26, 2013, during one of the Flood Recovery Team's daily meetings, the department flagged annexations as an important policy issue.

Soon after the flood, the residents of these properties contacted the Public Works Department and asked if they could be connected to the city sewer main. According to city regulations, only residents living within city limits can obtain city sewer and water services, so these properties would have to be annexed to the city to obtain these services. City

13 Boulder is a member of the UDFCD, a regional district of municipalities in the Denver metropolitan area that provides guidance to local governments on issues of drainage and flood control. The UDFCD coordinates floodplain mapping activities within the region. 
officials sought to expeditiously annex properties facing these issues, however, there were technical and financial hurdles to proceeding with annexation:

- City officials had difficulty ascertaining the condition of the wells and wastewater systems on potential properties to annex. As a result of varied levels of contamination across properties, city officials had difficulties gauging whether there was support for connecting to city utility services;

- The process of annexing a property and connecting to city services was cost prohibitive. High costs associated with installing a connection to city utilities have were addressed in prior acquisition efforts through the city subsidizing or providing financing support to homeowners that were annexed. Identifying the level of financial support for annexation construction cost subsidy was identified as a critical policy issue for a successful annexation program; and

- Costs associated with annexation also burden municipal government agencies, as the annexation process including providing financial support is a timeintensive process for city employees (Brautigam and Fetherston 2013a).

On December 3, 2013, the Planning, Housing, and Sustainability Department presented this issue to the City Council and proposed a streamlined process, which included waiving certain fees and offering 10-year financing plans to these residents. In March 2014, an updated proposal was finalized. In spring of 2014, the city made offers to the 160 affected property owners. By March 2016, when the offer for the amended annexation process had closed, the city had annexed 27 properties, with 3 in the annexation process (City of Boulder 2016h).

\section{d. Acquisition of properties in high hazard zones}

No properties were acquired as a result of the flood. The city did offer to buy out a few property owners in the high hazard zone, but the property owners declined the offer. As described in the pre-event preparedness section, the city has a high hazard zone acquisition fund - a subset of the Stormwater and Flood Management Utility-for properties in the high hazard zone of the floodplain.

\section{e. 100 Resilient Cities Initiative and the City of Boulder resilience strategy}

The City of Boulder was one of the initial cities selected in December 2013 for the Rockefeller Foundation's 100 Resilient Cities Initiative. This selection was accompanied by funding for a 2-year Chief Resilience Officer (CRO) position within the city government and access to technical support and tools. The city hired a CRO, who began work in September 2014 (City of Boulder 2014a). The CRO in each of the 100 Resilient Cities participating cities leads the resilience effort within their local government and is 
responsible for producing a resilience strategy — a roadmap that outlines the city's highest resilience priorities and activities to support those priorities.

In 2014, the City of Boulder kicked off its participation in the 100 Resilient Cities Initiative through a workshop intended to gather community input about resilience priorities. In the same year, the city initiated a resilience assessment designed to inform the writing of its resilience strategy. When the city began to write the strategy, officials recognized that for the document to be effective, the city would need to integrate it into and build upon existing documents and processes, including the 2015 update to the Boulder Valley Comprehensive Plan. The city released a draft version of the City of Boulder Resilience Strategy for public comment on April 28, 2016 (City of Boulder 2016f). The document outlined three major strategies for the city:

- Connect and Prepare. Prepare all segments of the community for uncertainty and disruption by encouraging community preparedness, creating a culture of risk awareness and personalizing resilience

- Partner and Innovate. Capitalize on the collective problem-solving and creativity of the community by leveraging advances in data, research, and observations to address emerging resilience challenges

- Transform and Integrate. Embed resilience into city operations and systems by transforming the city's approach to community resilience

Each strategy has four to six priority actions that the city intends to implement within the 2 to 3 years following the release of the strategy. The plan also describes "frontier" actions, which represent efforts that require broader community engagement for successful implementation. ${ }^{14}$ Some of these actions include the following:

- Facilitate the use of continuity planning strategies with local businesses (Connect and Prepare);

- Develop rapid post-disaster impact assessment capacity in partnership with the local business community (Connect and Prepare);

- Prioritize city investments to promote community resilience and proactively address future risks (Frontier Activity) (Connect and Prepare);

- Develop a sustainable, secure, and equitable energy system (Frontier Activity) (Partner and Innovate);

- Ensure the continuity of all critical life-safety services at a network of community resilience centers (Transform and Integrate); and

14 The City of Boulder Resilience Strategy defines a "frontier" activity as "transformative investments in community resilience that currently have no models to emulate, represent extremely complex areas for action and/or require an extensive community conversation to be successful" (City of Boulder 2016f, 24). 
- Integrate resilience principles into Boulder's Sustainability Framework (Transform and Integrate)

\section{Open Space and Natural Resources}

\section{a. Reimbursements for trail maintenance and constructed wetlands through FEMA public assistance}

FEMA public assistance reimburses engineered systems, which, for OSMP, includes engineered trail construction, pedestrian bridges, culverts, and some of the visitor infrastructure at trailheads. The total damage to trails and open space, as assessed by the City of Boulder, was approximately $\$ 8.3$ million (Brautigam and Rait 2015). Some of the city's wetland and riparian habitats experienced considerable damage during the flood, which is included in the $\$ 8.3$ million estimate. FEMA, however, does not include habitat restoration as a reimbursable expense.

FEMA representatives calculated that of the $\$ 8.3$ million in damages, $\$ 5$ million of the cost of restoration and rebuilding was reimbursable. This $\$ 5$ million reflects the engineered systems that fit within the agency's requirements for reimbursement.

In late 2014 and early 2015, OSMP conducted field tours with representatives from FEMA to the open spaces and trails, demonstrating that the trail systems were engineered systems eligible for reimbursement. The city representatives demonstrated that OSMP had expended resources engineering the trails and culverts to be more sustainable and resilient against flooding. FEMA officials originally provided a $\$ 2$ million estimate for trail damage reimbursement but increased the figure to $\$ 5$ million after the fieldtrips.

By early 2015, OSMP had categorized the different types of systems under its jurisdiction (e.g., engineered trails and bridges) and coded them as restoration and rebuilding projects. After this step was completed, OSMP officials began the design phase for these projects. OSMP had adequate staff for designing and rebuilding but not for permitting. Each design had to be reviewed by an ecologist. OSMP had wetland and wildlife ecologists on staff, but a bottleneck emerged during the review phase because of insufficient staffing to process ecological reviews. OSMP applied for and received an 18-month grant to fund a temporary position to help alleviate the bottleneck. OSMP also received approval from the Open Space Board of Trustees (OSBT) ${ }^{15}$ and the City Council to create a similar 3-year, fixed-term position to support the review process. The

15 The OSBT is a five-member advisory board appointed by the City Council. This board has more power than the other City of Boulder advisory boards. On all property acquisition and disposition decisions, the OSBT must affirmatively act in order for the action to be approved. If the OSBT does not act affirmatively, the decision does not go to the City Council. The City Council cannot overturn the board's decisions. The OSBT serves an advisory role on the budget and makes budget recommendations 
supplemental appropriations for this position was passed by OSBT on March 17, 2015 (Open Space Board of Trustees 2015).

\section{b. Engineered structures and sustainably designed trails}

The trails built using sustainable design techniques fared better than the historic, traditionally-built trails that followed fault lines. ${ }^{16}$ The department staff provided evidence of these improved outcomes to the OSBT to demonstrate that the sustainable design standards had been effective and performed as anticipated.

OSPM staff are currently engaging with the public about rebuilding bridges that were washed out and establishing design levels for their restoration: (1) rebuild them as smaller, easily replaceable bridges that may be washed out during subsequent floods or (2) rebuild them as larger bridges built to withstand 100-year flood loads. A similar debate is also taking place bout the overall rebuilding strategy and whether to keep the natural aesthetic of the trails and parks or to increase the number of engineered systems and structures.

\section{Summary of Long-Term Recovery Actions and Decisions}

\section{a. Infrastructure actions and decisions}

- Approved long-term capital investment program investments: In 2015, the City Council approved a 6-year CIP budget to address infrastructure upgrades throughout the city and also approved increases in utility rates to support an accelerated wastewater infrastructure replacement program. These investments accelerated the wastewater pipeline replacement time frame from 100 years to 20 years.

- Continued stormwater infrastructure investments: The city continues to implement programs to remap waterways with updated floodplain maps, with the objective of engineering waterways to 100-year flood design standards. In some waterways, due to the location of some properties in the high hazard zone of the floodplain, the city cannot implement 100-year flood design standards without acquiring those properties. The city is exploring other options to upgrade these waterways, including through property acquisitions.

- Proposed upgrades to Boulder Reservoir supply canal: Boulder Reservoir's supply source is an open canal that experienced high sediment loads in the 2013 flood. The Public Works Department has proposed to build a pipeline to replace the canal to mitigate these risks in future flooding events. The project would be funded through the city's CIP budget.

16 OSMP Department Presentation to OSBT (City of Boulder 2013b). 


\section{b. Actions and decisions to meet community needs}

- Annex flood-affected properties within Boulder County: After the 2013 flood, 160 properties in unincorporated Boulder County that were adjacent to the City of Boulder sought to connect to city utilities due to damage and contamination of privately owned water and wastewater systems. In 2013, the city offered to annex these properties and offered finance plans to recover the costs of connecting to city utilities. As of March 2016, the city has annexed 27 properties.

- Engage public in stormwater management projects: The city has held public events to engage with and solicit the input of residents on stormwater management strategies and projects. Low-frequency, high-consequence events present challenges in explaining rationales and tradeoffs associated with various flood mitigation options. Flood management initiatives that are jointly funded and planned by several city departments, such as the Greenways Program, increase the exposure of residents to the types of investments and flood mitigation projects considered by the city.

\section{- Engage public on sustainably designed trails during OSMP rebuilding:} OSMP staff engaged residents to seek input on how to rebuild bridges and structures damaged or destroyed in the floods. OSMP also sought input on the design standards that trail and park users preferred, recognizing the tradeoffs between robustness of design to flood loads, aesthetics, and ecological conservation. Sustainable trail designs were applied to rebuilt trails to reduce risks posed by future floods to the trails, reduce impacts on natural systems, and reduce maintenance costs. 


\section{Case Study 3: Towns of Lyons and Jamestown}

\section{A. Lyons: Long-Term Recovery Actions and Decisions}

Lyons, Colorado, is a town in northern Boulder County. It is located 14 miles north of Boulder and sits at an elevation of 1,637 m. (5,371 ft.). It has approximately 2,000 residents and a median household income of $\$ 90,603$ (U.S. Census Bureau 2010, 2015). The town sits at the confluence of two creeks - the North and South St. Vrain Creeks. The local economy depends on tourism, stemming from the town's location near Rocky Mountain National Park and the town's music and cultural events. Nearly all of the businesses in Lyons are owned locally.

The town government is comprised of five departments (Building Department, Transportation Department, Finance Department, Public Works Department, and Parks and Recreation Department) and two offices (Town Clerk's Office and Town Administrator's Office) that provide resident services. The government is led by a mayor, a town administrator, and a Board of Trustees. The seven-member Board of Trustees has five elected trustees and the elected Mayor and Mayor Pro Tem (Town of Lyons 2016a).

Electric and wastewater utilities are provided by the town of Lyons, while water is provided by the City of Longmont. The city fills its public safety and law enforcement needs through contracts with the Boulder County Sheriff's Office (Town of Lyons 2016c).

\section{Infrastructure Recovery}

\section{a. Water and wastewater}

Lyons's public wastewater and drinking water systems were destroyed in the flood. The municipal water tank is about 3 miles outside of town, and the main line connecting the town to the Longmont distribution network was severely damaged during the flood. The wastewater treatment plant was inundated, and the wastewater collection system was damaged extensively.

Lyons officials prioritized the restoration of the wastewater services due to public safety considerations. As an interim wastewater service restoration measure, Lyons officials were able to run the wastewater lines above ground and heat wrap them for insulation (to provide service through the winter months). The municipal water and sewer 
services were first restored for a portion of residents and businesses on October 26, 2013 (Town of Lyons 2014).

Due to the expansion of the creek floodplain into the original buried water and wastewater infrastructure right-of-ways, new infrastructure siting engineering design challenges would have to be addressed in a permanent infrastructure restoration solution.

The town awarded a Longmont construction company a bid for a project in the Confluence Area, as a capital improvements project. The timeline for this project was announced as fall 2015 through summer 2016 (Town of Lyons 2016b). The project included the following upgrades and repairs:

- Replacing water mains and sewer mains,

- Installing storm drains,

- Reconnecting utility services, and

- Laying asphalt pavement and a concrete curb/gutter.

\section{b. Roads}

Over a mile of local roads and two bridges were damaged. The road between Lyons and the town of Estes Park, which takes residents and tourists into Rocky Mountain National Park, was reopened on November 4, 2013 (Town of Lyons 2014).

\section{c. Houses}

More than 20 percent of residences (215 homes, 43 of which were mobile homes) were substantially damaged or damaged. Most of the affected homes were in the Confluence neighborhood and along the St. Vrain corridor. The town was able to find temporary housing for displaced residents, including the use of recreational vehicles, if necessary (Town of Lyons 2014).

Displaced residents were unable to immediately return home after the floods. As of February 2014, 145 households (totaling 310 people) were still displaced. One issue that slowed this process was the unavailability of land. Floodplain regulations and building codes prohibited rebuilding houses in the designated floodplain. In addition, the median income of displaced households was 50 percent lower than the town median, making affordability another barrier to returning and rebuilding (Town of Lyons 2014).

To address these issues, Lyons officials began a two-pronged approach to reinstate safe and affordable housing in the town. This effort has included encouraging the use of

prefabricated, modifiable housing units. Town officials also evaluated existing building regulations and codes and sought to identify ways to improve regulations to streamline the rebuilding processes and ensure that the town's built environment would be more resilient 
to future floods. One solution to the housing problem was a public initiative to use portions of park space for new low-income housing.

\section{d. Public buildings}

The public works building, sewage treatment plant, parks maintenance facility, town hall, town schools, and library were damaged or destroyed. The Lyons government operated out of the Longmont city council chambers until its town hall was rebuilt. A local television station covered meetings and provided announcements so that displaced Lyons residents were aware of decisions made about rebuilding and recovery. The town hall was reopened on December 22, 2013. All 744 elementary, middle, and high schoolers were relocated to an administration building in Longmont for 3 months, until the schools in Lyons were reopened in December 2013 (Town of Lyons 2014).

\section{e. Debris and stormwater management}

The drainage system in the southern part of Lyons had accumulated debris during the flood and needed to be cleared. Boulder County provided resources and aid to assist with debris removal. The town of Lyons coordinated with the Boulder County Department of Transportation to clear debris and improve creek flow, particularly in areas near bridges. The town is looking into ways to collaborate with the Boulder County Park and Open Space Department to develop water detention basins along the South St. Vrain Creek. It is also exploring opportunities to provide temporary floodwater storage capacity using large gravel pits that are on open space land to create a series of emergency detention basins that could function during periods of high water (Town of Lyons 2014).

\section{f. Creek restoration and stabilization}

In an effort to repair the St. Vrain Creek, Lyons planted vegetation along the creek corridors to improve the riparian habitat and stabilize the banks. Streambed stabilization and habitat restoration is outside FEMA's jurisdiction for flood assistance, so much of this work was supported by funding from the United States Department of Agriculture (USDA) National Resource Conservation Service (NRCS). In early 2014, repairs to the St. Vrain were estimated to cost more than \$20 million (Town of Lyons 2014).

The town plans to add improvements, such as rock formations, walls, and riverbed tiering, to St. Vrain Creek to improve the ability of the creek to handle increases in water volume and velocity. To support environmental and tourism objectives, officials also plan on restocking the St. Vrain Creeks with native fish.

The town was awarded CDBG-DR funds for a St. Vrain restoration project. The town awarded a contract to a Greeley-based construction company for this project, which included revegetating, restoring the natural riparian ecosystem, adding rock formations, 
and slowing the flow of the creek, among other activities. The grant dictated that the project must be completed by March 2016 (Town of Lyons 2016d).

\section{g. Policies and planning}

Lyons sought to repair infrastructure and to ensure that structures were built to higher standards in case of future flooding events. Town officials updated the Long Range Water Plan, the Master Wastewater Plan, the Storm Drainage Master Plan, and the All Hazard Mitigation Plan to reflect lessons learned during the flood. The town also sought to increase post-disaster mobility by developing an integrated multi-modal transportation corridor through the town as described in the Recovery Action Plan.

The Lyons Recovery Action Plan is a recovery planning document, written with input from community members about recovery decisions and objectives and technical support from external partners, such as FEMA, the University of Colorado Denver, and the Colorado Department of Local Affairs. The process for developing the Recovery Action Plan began in December 2013, under the direction of three guiding principles: sustainability, resilience, and resident-driven. A draft plan was released on March 17, 2014, and a final version was approved by the Board of Trustees on March 31 (Town of Lyons 2014).

The Lyons Area Urban Renewal Plan was prepared by a contracted real estate advisory firm in November 2015 to meet regulatory requirements for the Lyons Urban Renewal Authority (Ricker|Cunningham 2015). Some of the projects described in the Lyons Recovery Action Plan were advanced further by the Urban Renewal Plan, such as:

- Encouraging the construction of affordable and manufactured housing,

- Developing a capital improvement plan, and

- Exploring a potential centrally located town municipal facility (either as new construction or as an upgrade to the existing facility).

\section{Community Needs}

\section{a. Volunteer and recovery coordination}

During the recovery from the flood, more than 60,000 volunteers supported recovery needs. The town of Lyons initially appointed a temporary staff member tasked with coordinating the volunteers but quickly recognized that additional coordination resources would be necessary due to the magnitude of volunteer support. The Foothills United Way organization assisted this effort by sending two staff members to Lyons to support broader volunteer and recovery coordination. 
To improve long-term community health and service provisions, the Lyons Town Board plans to establish a Health and Human Services Commission and add a Health and Human Services chapter to the Lyons Comprehensive Plan. The Commission would be responsible for coordinating health and human service programs in Lyons and facilitating resident access to these services. The Human Services and Aging Commission (HSAC) was established between March 2014 and January 2015 to fill this role. The mission of the HSAC is to coordinate with local governmental and non-governmental entities to provide human services and identify unmet needs in the Lyons area (Town of Lyons 2014). The Lyons Emergency Assistance Fund (LEAF), which was founded in 2008, has also provided human services for flood-affected residents in Lyons. The non-profit organization reported that in 2015, it assisted 115 individuals through its Displaced Resident Advocate and 40 households through fast-track rebuilding (LEAF 2016). As of February 26, 2015, the HSAC had completed or made progress on each of the Health and Human Services Commission priority actions called for in the Lyons Recovery Action Plan.

\section{b. Local business and economic recovery}

The Lyons business community was affected by the physical damage to storefronts and the loss of revenue that resulted from a decline in the number of customers. Businesses were closed to customers for at least 6 weeks after the flood (some longer) and, in total, lost approximately $\$ 3.5$ million in sales. The town of Lyons anticipated a 10 percent fall in General Fund revenues (about half of which comes from sales tax) for 2013 and a 30 percent decline in sales tax for 2014 (Town of Lyons 2014).

As a result, Lyons prioritized the revitalization of its business community in its longterm recovery planning. In addition to pursuing disaster aid funds to help revitalize economic activity interrupted by the flood, the town looked for ways to increase interest in and visitors to Lyons. These efforts included projects such as increasing the digital profile of the town and its businesses, seeking to lower energy costs to local businesses, rebuilding the main street area using local building materials, and supporting year-round weekly events.

\section{B. Jamestown: Long-Term Recovery Actions and Decisions}

Jamestown, Colorado, is a small mountain town in Boulder County, approximately 12 miles northwest of the City of Boulder. The town sits on the James Creek, above the confluence of Little James Creek and Left Hand Creek. Before the 2013 flood, the town had a population of 274 residents in approximately 125 housing units (Town of Jamestown 2015b). Jamestown's Main Street is the only paved street in town. All other roads are unpaved. Within the town, institutions such as the sole elementary school, the town hall, the community church, the volunteer fire department, and the post office provide key community services. Public services commonly provided to households in urban areas, 
such as mail delivery, are only provided at the town post office. Public drinking water service is the only utility service that the town government provides to the residents.

\section{Infrastructure Recovery}

The town water treatment facility was the primary facility damaged by the flood. No water service was provided in the first 10 months after the flood. During the repair process, donated water cisterns allowed 98 residents to return home. The water distribution network was repaired by August 2014, and the water treatment facility was repaired and back online in November 2014 (Town of Jamestown 2016d).

The road network within the town was severely damaged. Some roads were destroyed, and bridges in town were washed away. County Route 94, the primary route for access to the town, was severely damaged. As of 2014, the town had restored all primary unpaved roads and the county had temporarily resurfaced County Route 94. As of December 2015, it had implemented a series of culvert and drainage improvement projects. The town has also assessed replacing the Main Street Bridge crossing James Creek as part of floodplain improvement efforts. As of December 2015, it had determined that a dualspan replacement of this bridge would exceed the town's financial capacity (Town of Jamestown 2015b).

In efforts to limit future flood losses, the town government implemented a moratorium on issuing building permits for new construction immediately after the flood. Once the town established a provisional floodplain map in January 2014, the town lifted the building permit moratorium.

As of August 2016, Jamestown is intending to contract the development of a drainage and stormwater master plan with the proceeds from a Phase 3 CDBG-DR grant award from Boulder County. The master plan report is scheduled to be completed in late 2017 (Town of Jamestown 2016c).

\section{Community Needs}

The impact of the 2013 flood created extraordinary community service needs - over 90 percent of the town's population was displaced. Recognizing the severity of the flood's impact on the town, and the need to take action to avoid future flooding and disaster losses, the town began a long-term recovery planning process in September 2014. The development of a long-term recovery plan was intended to guide the town's leadership in the rebuilding process in support of several community objectives, including making the community more resilient to future events.

This planning process was supported by a grant provided by the Colorado Department of Local Affairs. Organized by a 21-community member planning advisory team, Jamestown community members implemented a participatory planning process to establish 
objectives and recovery principles for future town and Jamestown area recovery investments. Based upon community input provided in a kickoff event held in September 2014, the recovery plan was organized around six core themes:

- Healthy Local Government and Safe Community,

- Supportive Community Services,

- Getting Around Town,

- Living with Nature,

- Land Use and Housing, and

- Vibrant Community Assets.

The Jamestown Long-Term Recovery Plan is organized into these six focus areas, each of which describes projects or initiatives to be considered for implementation by the town government. Future disaster mitigation projects include revising emergency management plans, coordinating with the Inter Mountain Alliance (IMA) for a communitywide preparedness group, increasing financial resources for fire and emergency services, providing backup power for critical facilities, and promoting activities to mitigate wildland fire risk. Notable financial projects include guidance to the town government to explore levying or raising taxes to increase government revenues without relying on town growth. The Long-Term recovery Plan was adopted by the town board in April 2015 (Town of Jamestown 2015b).

In 2015, the town of Jamestown published a Hazard Identification and Risk Assessment (HIRA) and Housing and Land Use Analysis report. The development of this report was supported through a grant from the CDBG-DR program. The publication of this report makes the town of Jamestown eligible for grants from FEMA's HMGP. The report analyzes the risks posed by wildfire, flooding, and geologic hazards. Recommendations resulting from the analysis described in the HIRA encourage continued efforts to mitigate and prepare for wildfire risk (i.e., update the town Community Wildfire Protection Plan, participate in the national Firewise Program), consider adopting Boulder County's amendment to the building code for fire risks, update the floodplain ordinance passed in 2012 adopting floodplain management principles promoted by FEMA, and identify funding to maintain a floodplain administrator after grant support ceases in summer 2016 (Town of Jamestown 2015a).

Following the publication of these plans and processes that elicited community member feedback on the flood recovery goals of the community, in 2016, the town of Jamestown began a process of updating its Comprehensive Plan. The last update to the town Comprehensive Plan was in 1981. Updates for the Comprehensive Plan are currently ongoing. Proposed updates to the plan in drafts published by the town incorporate recommendations included in the adopted Long-Term Recovery Plan and 2015 HIRA 
report (Town of Jamestown 2016b). Town Board review and approval is expected in 2017 (Town of Jamestown 2016a). 


\section{Summary and Conclusion}

The efforts of Boulder County, the City of Boulder, and the towns of Lyons and Jamestown focused on serving community needs throughout the recovery from the 2013 flood. At the same time, the communities were afforded opportunities to implement enhanced design standards for rebuilding infrastructure, buildings, and public facilities that would be more likely to survive or mitigate damage in future flooding events. This chapter summarizes resilience practices observed and lessons learned from the case studies.

The chapter is organized into two subsections. The first describes practices or lessons learned related to resilient infrastructure design, planning, and programmatic implementation. The second describes efforts by the municipal governments to ensure community needs were met.

\section{A. Infrastructure Design, Planning, and Programmatic Implementation}

\section{Strategic Stormwater and Flood Management Planning Provided Long-Term Guidance for Investments in Flood Management Infrastructure}

Comprehensive flood management plans made it possible for agencies to create longterm policies for stormwater management in Boulder County communities. The plans provided strategic guidance that allowed agencies to plan for regulatory, financial, and program requirements to meet flood management goals.

\section{Designing Stormwater Programs That Incorporated a Broad Array of Initiatives Increased Flexibility of Program Managers to Meet Community Objectives}

Stormwater and flood management programs supported by many government agencies made it possible to implement long-term infrastructure projects and to take mitigation measures as opportunities arose. Boulder County communities used floodplain mapping and risk assessments to inform planning for flood management, engineered waterways, and flood control structures, land-use restrictions, high hazard property acquisition programs, and facility flood-proofing requirements. 


\section{Engineered Waterways Can Serve Many Community Objectives, Including Flood Management, Ecological Preservation, Recreation, and Cultural Resource Preservation}

Boulder County communities have been able to use engineered waterways to provide public services and maintain flood control. Boulder's waterways serve as public facilities for recreation and cultural activities. Infrastructure that is developed to provide these services and support flood loads enhances public amenities and avoids flood losses.

\section{Up-to-Date Floodplain Maps Remain the Primary Input for Effective Designs to Mitigate Damage from Floods}

Boulder County communities are updating floodplain maps and pairing them with risk assessment methodologies to identify vulnerabilities in infrastructure and buildings. The maps and risk assessment methodologies estimate the expected impacts and consequences of flooding, and improve mitigation project planning. After the 2013 flood, many Boulder communities were motivated to create new FIRMs.

\section{Boulder County communities Implemented Resilient Design Performance Standards for Infrastructure and Dependent Facilities}

Boulder County communities, led by staff from the City of Longmont as the lead agency for the Boulder County Collaborative, developed a resilient design performance standard through a collaborative planning process that required the development of timeto-recovery goals for different types of infrastructure in each community. Boulder County officials used the process outlined by the NIST Community Resilience Planning Guide for Buildings and Infrastructure Systems. Officials employed a three-step process for evaluating proposed infrastructure projects against the design standards established by each community.

\section{Infrastructure Interdependencies Were a Significant Source of Vulnerability}

Several critical facilities that rely upon infrastructure networks, such as roads, the electric power system, and canals, were vulnerable to network failures and site-specific impacts. Impacts resulting from interdependencies with other infrastructure systems were avoided through emergency responses and redundancies in infrastructure. Plans to address these vulnerabilities include hardening dependent infrastructure, such as the proposed upgrades pipe the water supply to the City of Boulder's Colorado Big Thompson/Boulder Feeder Canal. 


\section{Regulatory Measures Were Implemented to Ensure That Critical Public Safety and Lodging Facilities Would Be Operational after a Flood.}

A primary motivation for implementing these regulations was a desire to support vulnerable populations and to ensure that future initial recovery objectives could be achieved. Compliance options included facility flood proofing, relocation, and development of emergency plans for facilities in 100- or 500-year floodplains.

\section{B. Administration of Recovery Efforts to Serve Community Needs}

\section{DACs and the Flood Recovery Center Streamlined the Provision of Community Services}

Boulder County communities provided coordinated public services for residents affected by the flood. Officials in DACs coordinated recovery funding support and provided case management services to engage other recovery services (e.g., issuing permits and conducting rehabilitation). The DACs served immediate county needs in the first 2-3 weeks after the flood. The county's Flood Recovery Center was established for longerterm community service support, and coordination across multiple departments and across multiple local governments.

\section{A Government Interdepartmental Coordination Function Was Established to Facilitate Recovery-Phase Efforts}

During the recovery phase, public service roles relied upon the ability of Boulder area governments to coordinate across several departments, while maintaining non-emergency roles and responsibilities. While emergency management coordination is provided through the activation of emergency supporting functions in the EOC, recovery functions that are integrated with traditional municipal departmental roles require interdepartmental coordination. City officials were successful in implementing a coordination structure that allowed for decisions pertaining to infrastructure, finance, and community service to be made during the recovery via interdepartmental coordination while maintaining staff in conventional departmental roles.

\section{Additional Structure and Protocols Were Needed to Transition Municipal Government Roles and Responsibilities from the Response Phase to the Recovery Phase}

Transitioning from the response-phase responsibilities articulated in the emergency support functions to the recovery-related roles and responsibilities was not seamless. Planning for the transition from response to recovery through, for example, the City of Boulder's proposed transition functions, would allow officials to meet responsibilities that 
occur at the boundaries between response and recovery roles, while they also prepare for longer term recovery roles.

\section{Early and Sustained Engagement with Community Members Who Provided Input to Recovery Planning Helped Government Officials Implement Effective Restoration Plans}

Boulder region officials relied upon participatory processes and community engagement to understand the effect of the flood and receive input on how to approach rebuilding and recovery. Through formal outreach meetings, facilitated workshops, and informal community activities, community members participated in policy decisions and flood management project decisions pertaining to the recovery.

\section{Elected Officials Provided Emergency Waivers and Granted Government Agencies Special Authorities to meet Public Service Needs during Recovery}

Elected government bodies in Boulder County passed emergency ordinances that provided government agencies the authority to relax regulatory requirements or impose temporary moratoriums on rebuilding to ensure the public safety of rebuilt structures. These recovery-phase authorities allowed government agencies to reduce the administrative burden of rebuilding, to remove financial disincentives associated with complying with building permit and safety approval processes, and to ensure building code compliance in restored or rebuilt structures.

\section{Budgetary Reserves for Emergencies Provided Communities the Flexibility to Prioritize Local Needs and Requirements and Provided Funding for Administrative Requirements for Later Reimbursement through Federal Disaster Assistance}

The Boulder region communities and governments that had financial reserves for emergencies or disasters were able to begin implementing restoration projects quickly with pre-approved contractors and to prioritize immediate community emergency and recovery needs without additional budgetary approvals. Recovery-phase projects could be prioritized by locally relevant needs without consideration of immediate budgetary consequences or FEMA Public Assistance Program eligibility and requirements.

\section{The Boulder County Collaborative Provided Governmental Decision-Making Capacity across Several Jurisdictions in the Region Where Flooding Took Place}

The Boulder County Collaborative, established to support the CDBG-DR application and allocation process, provided the administrative and decision-making capacity to prioritize funding decisions pertaining to long-term recovery. When regional disaster assistance support is provided by the Federal Government, these decisions often take place 
at the level of the State Government. Regional intergovernmental collaboration allowed Boulder County governments to set priorities for recovery-phase resources and projects.

\section{Boulder Community Officials and Local Non-Profit Organizations Recognized the Role of Resident-Led Organizations in Addressing Long- Term Recovery Needs}

Local area non-profit organizations and local governments created the Long-Term Flood Recovery Group to coordinate the county's long-term recovery efforts. An independent, collaborative, resident-led organization called BoCo Strong was formed by county residents involved in the recovery process who recognized the need to form and strengthen community social networks and resilience infrastructure in anticipation of future disasters. BoCo Strong has taken on efforts that are outside traditional county government roles, including the formation of a resilience network, resilience leadership training, and coordinating the county's VOAD. 


\section{Appendix A. Discussion Topics}

The following types of questions and topics were discussed during conversations with community members from Boulder County, the City of Boulder, and the town of Lyons.

\section{Questions for Community Leaders at the November 2015 Kickoff Meeting}

1. How was your community impacted by the 2013 floods, particularly regarding

a. Community functions (including food/water, health, housing/shelter, safety/security, personal growth/development, culture, and belonging)?

b. Services (i.e., communication, transportation, water and sewage, energy, governance, policing, fire protection, social services, education, commerce, recreation, and so forth)?

c. Built and natural infrastructure resources and components?

2. What did/does the recovery process look like in your community following the 2013 floods?

a. Were there any planning efforts undertaken to prepare for the recovery phase? If so, who was in involved in planning?

b. In implementation? (e.g. private contractors, non-profits, volunteer organizations)

3. What are the sectors and services that have fully recovered? Where is the recovery still in progress?

4. How can we learn more from you and your community members through our case study?

\section{Questions for Follow-Up Conversations}

1. Contextual information

a. What are you in charge of and what service does that system provide? 
b. At times of rest, what are the interdependencies of the system? Does [the system] rely on other systems in the community or do other systems depend on [the system]?

c. Before the flood, what (flood and non-flood) emergency planning was place?

2. Flood impact

a. What percentage of [the system] was impacted, and how severely was it impacted?

b. What were some key elements in the system and were they impacted?

c. At what point during the flood did you have to reduce the usage or completely close elements of [the system]?

If Yes: What was your reasoning for shutting down these elements of the system? Were you weighing several options?

3. Interdependencies

a. Did the impact on [the system] affect any other systems in the city?

b. Did the flood's impact on other systems in the city affect [the system]?

4. Recovery

a. How long did it take to recover [the system] to full capacity?

b. Did you prioritize certain elements in the recovery?

If Yes: Why were these prioritized? What was your thought process?

5. Lessons learned

a. Have there been any structural or procedural changes in [your organization] as a result of the flood?

b. Since the flood, what has changed in the emergency planning in place?

c. What were some best practices that were learned from the flood and the subsequent recovery? 


\section{Appendix B. \\ Community Contacts}

Table B-1. Contacts by Community or Organization

\begin{tabular}{|c|c|c|}
\hline $\begin{array}{l}\text { Community or } \\
\text { Organization }\end{array}$ & Name & Position \\
\hline \multirow[t]{14}{*}{ City of Boulder } & Bob Harberg & Principal Engineer \\
\hline & Cheryl Pattelli & Finance Director \\
\hline & Chris Meschuk & Flood Recovery Coordinator - Community Services \\
\hline & Chris Trice & Information Resources Manager \\
\hline & Christin Shepherd & Civil Engineer \\
\hline & Greg Guibert & Chief Resilience Officer \\
\hline & Jane Brautigam & City Manager \\
\hline & Jeff Arthur & Director of Public Works for Utilities \\
\hline & Jennifer Pinsonneault & Business Liaison \\
\hline & Joel Wagner & Special Assistant to Finance and the City Manager's Office \\
\hline & Maureen Rait & Public Works Executive Director \\
\hline & Mike Sweeney & Director of Public Works for Transportation \\
\hline & Susan Richstone & Planning, Housing, and Sustainability Deputy Director \\
\hline & Tracy Winfree & Open Space and Mountain Parks Director \\
\hline \multirow[t]{10}{*}{ Boulder County } & Dale Case & Land Use Director \\
\hline & Frank Alexander & Housing and Human Services Director \\
\hline & Garry Sanfaçon & Flood Recovery Manager \\
\hline & George Gerstle & Transportation Director \\
\hline & Joe Malinowski & Environmental Health Division Manager \\
\hline & Laura Seraydarian & Project Coordinator, Resilience and Capacity Building \\
\hline & Mike Chard & Office of Emergency Management Director \\
\hline & Ron Stewart & Parks and Open Space Director \\
\hline & Sarah Buss & Flood Recovery and Emergency Case Management Administrator \\
\hline & Tiernan Doyle & $\begin{array}{l}\text { Project Coordinator, Voluntary Organizations Active in Disasters } \\
\text { (VOAD) and Resilience Networks }\end{array}$ \\
\hline $\begin{array}{l}\text { Inter Mountain } \\
\text { Alliance (IMA)/ } \\
\text { Foothills United Way }\end{array}$ & Amy Hardy & Chair/Community Resilience Director \\
\hline $\begin{array}{l}\text { Institute for Social and } \\
\text { Environmental } \\
\text { Transition (ISET) }\end{array}$ & Karen MacClune & Chief Operating Officer and Senior Staff Scientist \\
\hline \multirow[t]{2}{*}{ City of Longmont } & Kathy Fedler & Housing and Community Investment Manager \\
\hline & Molly O’Donnell & $\begin{array}{l}\text { Resilience Planner and Project Manager, Community Development } \\
\text { Block Grant Disaster Recovery (CDBG-DR) Infrastructure Program }\end{array}$ \\
\hline Town of Lyons & Victoria Simonsen & Town Administrator \\
\hline
\end{tabular}




\section{References}

Arthur, Jeff, Bob Harberg, Joe Taddeucci, Bret Linenfelser, Ken Baird, Tom Settle, Chris Douville, et al. 2015. Water Resources Advisory Board Meeting, "Information Item - 2014 Year in Review." Boulder, CO: City of Boulder, Water Resources Advisory Board, January 26. https://wwwstatic.bouldercolorado.gov/docs/Complete_WRAB_Packet_2015-1-26-1201501161811.pdf.

BoCo Strong. n.d. "Recommended Actions for Greater Resiliency." Handout received from BoCo Strong in November 2015.

Boulder County. 2013. "DC-13-0003: Front Range Flood and Extreme Rain Text Amendments to Article 19 of the Boulder County Land Use Code." http://www.bouldercounty.org/doc/landuse/dc130003boccstaffrec20131023.pdf . 2015. CDBG-DR Unmet Needs Assessment: Boulder County. Boulder, CO: Boulder County, April 13. http://longmontcolorado.gov/home/showdocument?id=7332.

. 2016a. "Boulder County Comprehensive Plan." http://www.bouldercounty.org/property/build/pages/bccp.aspx.

_. 2016b. "Creek Recovery \& Restoration Program." http://www.bouldercounty.org/flood/creekrestoration/pages/default.aspx.

_. 2016c. "Floodplain Management." http://www.bouldercounty.org/property/flood/pages/default.aspx.

. 2016d. "Flood Recovery Resource Guide, Summer 2016." http://www.bouldercounty.org/doc/flood/floodrecoveryguide.pdf

- 2016e. "Hazard Mitigation Review." http://www.bouldercounty.org/flood/property/pages/hmr.aspx.

_. 2016f. "Minutes from Meeting of the Board of County Commissioners, Boulder County, Tuesday, January 26, 2016." http://bouldercountyco.suiteonemedia.com/web/UserControls/DocPreview.aspx?p= $1 \& \operatorname{mid}=474$

Boulder County CDBG-DR Collaborative. 2016. Resilient Design Performance Standard for Infrastructure and Dependent Facilities. http://www.bccollaborative.org/uploads/6/6/0/6/66068141/resilientdesignperforman cestandard_adopted_05.13.2016.pdf

Boulder County Keep It Clean Partnership. 2017. "Boulder County Watershed Map." http://www.keepitcleanpartnership.org/wpcontent/uploads/pdfs/WatershedMapInsert522.pdf. 
Boulder County Land Use Department. 2013. "Temporary Emergency Permits." http://www.bouldercounty.org/doc/landuse/b73temporaryemergencypermit.pdf.

_ 2014. Article 19. Boulder County Last Use Code. http://www.bouldercounty.org/doc/landuse/lucodearticle19.pdf.

Boulder County Transportation Department. 2016. "Proposed Floodplain Code Text Amendments." http://www.bouldercounty.org/doc/transportation/ floodplaincodeamendjuly26pres.pdf.

Brautigam, Jane S., Bob Eichem, David Driskell, Maureen Rait, Peggy Bunzli, Jean Gatza, Milford John-Williams, et al. 2015. City Council Study Session: Review of the Draft 2016-2021 Capital Improvement Program (CIP). Report to Members of the City Council. Boulder, CO: City of Boulder, August 11. https://wwwstatic.bouldercolorado.gov/docs/20150811_SS-1-201508061452.pdf.

Brautigam, Jane S., and Paul J. Fetherston. 2013a. September 2013 Flood EventPreliminary Findings. Report to Members of the City Council. Boulder, CO: City of Boulder, December 3. https://documents.bouldercolorado.gov/weblink8/0/ doc/124176/Electronic.aspx.

- 2013b. Update on Flood Recovery and Disaster Assistance Status and Consideration of Overarching Goals Regarding Cleanup and Flood Recovery Measures. Report to Members of the City Council. Boulder, CO: City of Boulder, September 27. https://documents.bouldercolorado.gov/WebLink8/0/doc/123780/Electronic.aspx.

Brautigam, Jane S., Paul J. Fetherston, Tom Carr, David Gehr, Maureen Rait, and David Driskell. 2013. "Second Reading and Consideration of a Motion to Adopt Emergency Ordinance No. 7946 Amending the Boulder Revised Code and Extending Temporary Exceptions to Specific City Regulations to Facilitate Clean Up and Recovery from Flood Impacts." Boulder City Council Meeting, Agenda Item 3A (Packet Pages 95-108). City of Boulder, CO: Boulder City Council, October 15. https://www-static.bouldercolorado.gov/docs/ 10.15.13_Final_Agenda_Packet_Electronic-1-201310110809.pdf.

Brautigam, Jane S., Paul J. Fetherston, Tom Carr, David Gehr, Maureen Rait, David Driskell, Hella Pannewig, and Dave Thacker. 2014. "Second Reading and Consideration of a Motion to Adopt Emergency Ordinance No. 7961 Amending Section 4-20-68, 'Flood Related Fee Waiver,' B.R.C. 1981, to Extend Temporary Authority to Waive Certain Fees to Facilitate Recovery and Repair Work Resulting from Flood Impacts." Boulder City Council Meeting, Agenda Item 3D (Packet Pages 80-85). City of Boulder, CO: Boulder City Council, February 18. https://www-static.bouldercolorado.gov/docs/ 20140218_Final_Agenda_Packet_Electronic-1-201402131436.pdf.

Brautigam, Jane S., and Maureen Rait. 2015. "Information Item: Flood Recovery Status." Information Packet Memorandum. Report to Members of the City Council. Boulder, CO: City of Boulder, January 20. https://www-static.bouldercolorado.gov/docs/ flood-recovery-status-memo-1-20-15-1-201501210855.pdf. 
Brautigam, Jane S., Maureen Rait, Susan Richstone, Hella Pannewig, David Thacker, and Chris Meschuk. 2015. "Introduction, First Reading and Consideration of a Motion to Publish by Title Only Emergency Ordinance No. 8035 Amending Section 4-2068, 'Flood Related Fee Waiver,' B.R.C. 1981, to Extend Temporary Authority to Waive Certain Fees to Facilitate Recovery and Repair Work Resulting from Flood Impacts and Amending Section 9-10-2 'Continuation or Restoration of Nonconforming Uses and Nonstandard Buildings, Structures, and Lots,' B.R.C., 1981, to Extend the Time to Resume Uses and Restore Buildings Affected by the September 2013 Flood." Boulder City Council Meeting, Agenda Item 3I (Packet Pages 194-201). City of Boulder, CO: Boulder City Council, March 3. https://wwwstatic.bouldercolorado.gov/docs/20150303_AgendaPacket_Final_website-1201502251558.pdf.

Brautigam, Jane S., Paul Fetherston, Maureen Rait, Jeff Arthur, Bob Harberg, Heidi Schum, Annie Noble, and Katie Knapp. 2013a. "Second Reading and Consideration of a Motion to Adopt Ordinance No. 7926, Amending Floodplain Regulations in Order to Clarify Existing Regulations and to Protect Critical Facilities and Lodging Facilities in the 100- and 500-Year Floodplains, Including Chapter 9-3 'Overlay Districts,' Subsection 9-6-1(d) 'Use Table,' and Section 9-16-1 'Definitions' B.R.C. 1981 and Motion to Adopt." Boulder City Council Meeting, Agenda Item 5A (Packet Pages 254-299). City of Boulder, CO: Boulder City Council, September 17. https://www-static.bouldercolorado.gov/docs/

09.17.13_Final_Agenda_Packet_Revised_Electronic-1-201309161746.pdf.

. 2013b. "Third Reading and Consideration of a Motion to Adopt Ordinance No. 7926, Amending Floodplain Regulations in Order to Clarify Existing Regulations and to Protect Critical Facilities and Lodging Facilities in the 100- and 500-Year Floodplains, Including Chapter 9-3 'Overlay Districts,' Subsection 9-6-1(d) 'Use Table,' and Section 9-16-1 'Definitions' B.R.C. 1981.” Boulder City Council Meeting, Agenda Item 3F (Packet Pages 153-202). City of Boulder, CO: Boulder City Council, October 1. https://wwwstatic.bouldercolorado.gov/docs/10.01.13_Final_Agenda_Packet_Electronic-1201309271640.pdf.

City of Boulder. 2004. Comprehensive Flood and Stormwater Utility Master Plan. Boulder, CO: City of Boulder, October. https://wwwstatic.bouldercolorado.gov/docs/comprehensive-flood-stormwater-utility-masterplan-1-201406101202.pdf.

. 2009. "Title 9: Land Use Code, Chapter 3 Overlay Districts, 9-3-2, Floodplains." Boulder, CO: City of Boulder. https://www.municode.com/ library/co/boulder/codes/municipal_code?nodeId=TIT9LAUSCO_CH3OVDI_9-32FL\&showChanges=true.

. 2011. Greenways Master Plan. Boulder, CO: City of Boulder. https://wwwstatic.bouldercolorado.gov/docs/2011-greenways-master-plan-update-1201304221316.pdf. 
. 2012. City of Boulder Multi-Hazard Mitigation Plan: Comprehensive Update. Boulder, CO: City of Boulder, October. https://www-static.bouldercolorado.gov/ docs/multi-hazard-mitigation-plan-update-2012-1-201303291127.pdf.

. 2013a. "City of Boulder and Boulder County to Open Disaster Assistance Center Today." https://bouldercolorado.gov/pages/sept-19-2013-city-of-boulder-andboulder-county-to-open-disaster-assistance-center-today.

. 2013b. "2013 Flood and Trail Sustainability.” Open Space and Mountain Parks Department Presentation. https://wwwstatic.bouldercolorado.gov/docs/Trail_Sustainability_PowerPoint-1201511061237.pdf.

. 2014a. "Boulder Hires First-Ever Chief Resilience Officer." https://bouldercolorado.gov/newsroom/aug-7-2014-boulder-hires-first-ever-chiefresilience-officer-2.

. 2014b. Flood Management Program. https://wwwstatic.bouldercolorado.gov/docs/Flood_Management_Program_Overview-1201410161244.pdf.

. 2014c. Summary Report of Private Property and Resident Flood Impact Survey and Analysis September 2013 Flood Disaster. Boulder, CO: City of Boulder, Utilities Division, December 3. https://www-static.bouldercolorado.gov/ docs/summary-report-private-property-resident-september-2013-flood-impactsurvey-analysis-1-201412031729.pdf.

. 2015a. After-Action Report: City of Boulder Flood Recovery. Boulder, CO: City of Boulder, September 9. https://www-static.bouldercolorado.gov/ docs/FINALCityBoulder2013FloodAAR-1-201601110830.pdf. . 2015b. City of Boulder Multi-Hazard Mitigation Plan: 2015 Annual Review. Boulder, CO: City of Boulder, Public Works Department. https://wwwstatic.bouldercolorado.gov/docs/2015_MHMP_Annual_Review_Final-1201510011156.pdf.

_. 2016a. "Bear Canyon Creek Floodplain Mapping Update." https://bouldercolorado.gov/flood/bear-canyon-creek-floodplain-mapping-update.

_. 2016b. "Boulder Creek Floodplain Mapping Update." https://bouldercolorado.gov/flood/boulder-creek-floodplain-mapping-update. . 2016c. "Boulder Slough Floodplain Mapping Update." https://bouldercolorado.gov/flood/boulder-slough-floodplain-mapping-update.

—. 2016d. "Capital Improvement Bond Projects." https://bouldercolorado.gov/bondprojects.

_. 2016e. "Capital Improvement Program." https://bouldercolorado.gov/planning/capital-improvement-program. . 2016f. City of Boulder Resilience Strategy, Draft for Public Comment. Boulder, CO: City of Boulder, April. https://www-static.bouldercolorado.gov/ docs/Resilience_Strategy_Draft_Low_Res-1-201605181503.pdf. 
- 2016g. "Critical Facilities and Lodging Facilities Ordinance."

https://bouldercolorado.gov/flood/critical-facilities-lodging-facilities-ordinance.

—. 2016h. "Flood-Related Annexations." https://bouldercolorado.gov/flood/

flood-related-annexations.

_. 2016i. "List of Capital Improvement Bond Projects."

https://bouldercolorado.gov/bond-projects/list-of-capital-improvement-bondprojects.

. 2016j. "Skunk Creek, Bluebell Canyon Creek, and King's Gulch Floodplain Mapping Update." https://bouldercolorado.gov/flood/skunk-creek-floodplainmapping-update.

_. 2016k. "Upper Goose Creek and Twomile Canyon Creek Floodplain Mapping Update." https://bouldercolorado.gov/flood/upper-goose-creek-and-twomilecanyon-creek-floodplain-mapping-update.

_. 20161. "2015 Utility Rates." https://bouldercolorado.gov/water/2015-utilityrates.

Colorado Water Conservation Board. 2017. "Colorado Hazard Mapping \& Risk MAP Portal: Floodplain Mapping" http://coloradohazardmapping.com/hazardMapping/floodplainMapping\#

Department of Housing and Urban Development. 2014. "Second Allocation, Waivers, and Alternative Requirements for Grantees Receiving Community Development Block Grant (CDBG) Disaster Recovery Funds in Response to Disasters Occurring in 2013." Federal Register 79, no. 106 (June 3): 31964-31973.

https://www.gpo.gov/fdsys/pkg/FR-2014-06-03/pdf/2014-12709.pdf.

Federal Emergency Management Agency. 2013. FEMA-4145-DR, Colorado Disaster Declaration as of 10/21/2013. http://gis.fema.gov/maps/dec_4145.pdf.

—. 2016a. "Freeboard." http://www.fema.gov/freeboard.

—. 2016b. "Hazard Mitigation Grant Program." http://www.fema.gov/hazardmitigation-grant-program.

_. 2016c. "National Disaster Recovery Framework." http://www.fema.gov/national-disaster-recovery-framework.

_ 2016d. "Community Rating System." https://www.fema.gov/media-librarydata/14762941627264795edc7fe5cde0c997bc4389d1265bd/CRS_List_of_Communites_10_01_2016.pdf

Graham, Russell, Mark Finney, Chuck McHugh, Jack Cohen, Dave Calkin, Rick Stratton, Larry Bradshaw, and Ned Nikolov. 2012. Fourmile Canyon Fire Findings. General Technical Report RMRS-GTR-289. Fort Collins, CO: U.S. Department of Agriculture, Forest Service, Rocky Mountain Research Station, August. http://www.fs.fed.us/rm/pubs/rmrs_gtr289.pdf.

Henson, Bob. 2013. "Inside the Colorado Deluge." AtmosNews, September 14. http://www2.ucar.edu/atmosnews/perspective/10250/inside-colorado-deluge. 
Jones, Roger, Ryan Piertramali, and Portia Ross. 2014. "Special Response Memorandum - Guidance for Use of Colorado Front Range Hydrologic Evaluations (Phase 1) in Complying with 44 CFR Part 9 and Executive Order 11988 (Floodplain Management) for Areas Seeing an Update.” Denver, CO: U.S. Department of Homeland Security, Region VIII, November 6. http://cwcb.state.co.us/watermanagement/flood/Documents/4145BestAvailableDataMemo.pdf.

Kimbrough, R.A., and Holmes, R.R., Jr., 2015, Flooding in the South Platte River and Fountain Creek Basins in eastern Colorado, September 9-18, 2013: U.S. Geological Survey Scientific Investigations Report 2015-5119, 33 p., http://dx.doi.org/10.3133/sir20155119.

LEAF. 2015 Annual Report. Lyons, CO: Lyons Emergency Assistance Fund. http://www.leaflyons.org/2015-leaf-annual-report.html.

McGhee, Tom. 2013. "Colorado Flood: No Relief in Sight as Record Rain Falls." The Denver Post, September 12. http://www.denverpost.com/2013/09/12/coloradoflood-no-relief-in-sight-as-record-rain-falls/.

National Weather Service. 2014. Service Assessment: The Record Front Range and Eastern Colorado Floods of September 11-17, 2013. Silver Spring, MD:

Department of Commerce, National Oceanic and Atmospheric Administration, June. http://www.nws.noaa.gov/om/assessments/pdfs/14colorado_floods.pdf.

National Institute of Standards and Technology. 2015. "Community Resilience Planning Guide for Buildings and Infrastructure Systems."

https://www.nist.gov/el/resilience/community-resilience-planning-guides.

Open Space Board of Trustees. 2015. "March 11 Meeting.” Agenda Item 3 (Page 2).

Boulder, CO: City of Boulder. https:/www-static.bouldercolorado.gov/docs/15-

0311-osbt-packet-1-201503120950.pdf.

Ricker Cunningham. 2015. Lyons Area Urban Renewal Plan. Centennial, CO: Ricker Cunningham, November. http://www.townoflyons.com/

DocumentCenter/View/491.

Robert T. Stafford Disaster Relief and Emergency Assistance Act, as Amended.

Pub. L. 93-288, 42 U.S.C. 5121 et seq. (2013). http://www.fema.gov/media-librarydata/1383153669955-21f970b19e8eaa67087b7da9f4af706e/ stafford_act_booklet_042213_508e.pdf.

Scott, Michon. 2013. "Historic Rainfall and Floods in Colorado." NOAA Climate.gov, September 17. https://www.climate.gov/news-features/event-tracker/historicrainfall-and-floods-colorado.

State of Colorado. 2015. "Substantial Action Plan Amendment \#3: Community Development Block Grant-Disaster Recovery (CDBG-DR).” June 26. http://nederlandco.org/wp-content/uploads/2015/07/State-of-Colorado-Amendment3-FINAL.pdf.

Town of Jamestown. 2015a. "Hazard Identification \& Risk Assessment, Housing and Land Use Analysis.” http://www.jamestownco.org/hazard-investigation-riskassessment-land-use-and-housing. 
. 2015b. "Long-Term Recovery Planning." http://www.jamestownco.org/longterm-recovery-planning.

_. 2016a. "Comprehensive Plan Update."

http://www.jamestownco.org/home/comprehensive-plan-update.

_. 2016b. "Comprehensive Plan 2016: Introduction."

https://docs.google.com/viewer?a=v\&pid=sites\&srcid=amFtZXN0b3duY28ub3Jnf HRvd24tb2YtamFtZXN0b3dufGd4OjM3ZjJkMDAwZjlkNjFmNzI.

—. 2016c. "Roads." http://www.jamestownco.org/roads.

—. 2016d. "Year-End Report 2015."

Town of Lyons. 2014. Lyons Recovery Action Plan. http://colyons.civicplus.com/DocumentCenter/View/388.

_. 2016a. "Board of Trustees." http://www.townoflyons.com/183/Board-ofTrustees.

_. 2016b. "Capital Improvements - Confluence Area Project." http://www.townoflyons.com/340/Capital-Improvements---Confluence-Area-P.

_. 2016c. "Departments. http://www.townoflyons.com/148/Departments.

_. 2016d. "St. Vrain Creek Restoration Project." http://www.townoflyons.com/339/St-Vrain-Creek-Restoration-Project.

U.S. Census Bureau. 2010. “2010 Census Data.” http://www.census.gov/2010census/data/.

_. 2015. "ACS Demographic and Housing Estimates: 2010-2014 American Community Survey 5-Year Estimates." https://factfinder.census.gov/ faces/tableservices/jsf/pages/productview.xhtml? src=bkmk.

Williamson, Eileen. 2013. "Colorado Flooding Brings Flood of Attention to Vital Regulatory Permitting Program." https://www.army.mil/article/114018/Colorado_flooding_brings_flood_of_attention _to_vital_regulatory_permitting_program.

Wright Water Engineers, Inc. 2014. Rainfall-Runoff Analysis for September 2013 Flood in the City of Boulder, Colorado. Denver, CO: Wright Water Engineers, Inc., October. https://www-static.bouldercolorado.gov/docs/rainfall-runoff-analysisseptember-2013-flood-boulder-colorado-1-201411180919.pdf.

Young, Quentin. 2013. "National Guard Carries Evacuees from Lyons, Delivers Supplies." Longmont Times-Call, September 12. http://www.timescall.com/longmont-local-news/ci_24072743/dam-break-threatenslyons-residents-warned-go-higher. 


\section{Abbreviations}

ACS

B.R.C.

BOCC

BoCo

CDBG

CDBG-DR

CIP

CRO

CRS

DAC

DMA

EGIS

EOC

EWP

ESF

FAQ

FEMA

FIRM

GPS

HHS

HIRA

HMA

HMGP

HSAC

HUD

IDA

IMA

ISET

LEAF

LOMR

LTFRG

NFIP

NIST

NRCS

OEM

OSBT

OSMP

PDM

PMR
American Community Survey

Boulder Revised Code

Board of County Commissioners

Boulder County (in reference to BoCo Strong)

Community Development Block Grant

Community Development Block Grant Disaster

Recovery

Capital Improvement Program

Chief Resilience Officer

Community Rating System

Disaster Assistance Center

Disaster Mitigation Act of 2000

Enterprise Geospatial Information Services

Emergency Operations Center

Emergency Watershed Protection

Emergency Support Function

Frequently Asked Questions

Federal Emergency Management Agency

Flood Insurance Rate Map

Global Positioning System

Housing and Human Services

Hazard Identification and Risk Assessment

Hazard Mitigation Assistance

Hazard Mitigation Grant Program

Human Services and Aging Commission

U.S. Department of Housing and Urban Development Institute of Defense Analyses

Inter Mountain Alliance

Institute for Social and Environmental Transition

Lyons Emergency Assistance Fund

Letter of Map Revision

Long-Term Flood Recovery Group

National Flood Insurance Program

National Institute of Standards and Technology

Natural Resources Conservation Service

Office of Emergency Management

Open Space Board of Trustees

Open Space and Mountain Parks Department

Pre-Disaster Mitigation

Physical Map Revision 
RSF

STPI

U.S.C.

UDFCD

USDA

VOAD

WRAB
Recovery Support Function

Science and Technology Policy Institute

United States Code

Urban Drainage and Flood Control District

United States Department of Agriculture

Voluntary Organizations Active in Disasters

Water Resources Advisory Board 